\title{
The Impact of miRNA in Colorectal Cancer Progression and Its Liver Metastases
}

\author{
Ovidiu Balacescu ${ }^{1,2, *,+}$, Daniel Sur ${ }^{2,3,+}$, Calin Cainap ${ }^{2,3,+}$, Simona Visan ${ }^{1,+}$, \\ Daniel Cruceriu ${ }^{1,4,+}$, Roberta Manzat-Saplacan ${ }^{5,6,+}$, Mihai-Stefan Muresan $7,8,+(\mathbb{D}$, \\ Loredana Balacescu $^{1,2,+}$, Cosmin Lisencu ${ }^{8,9,+}$ and Alexandru Irimie ${ }^{8,9,+}$
}

1 Department of Functional Genomics, Proteomics and Experimental Pathology, The Oncology Institute "Prof. Dr. Ion Chiricuta", Cluj-Napoca 400015, Romania; simona.visan19@gmail.com (S.V.); dani_cruceriu@yahoo.com (D.C.); loredana_balacescu@yahoo.com (L.B.)

2 11th Department of Medical Oncology, University of Medicine and Pharmacy "Iuliu Hatieganu", Cluj-Napoca 400015, Romania; dr.geni@yahoo.co.uk (D.S.); calincainap2015@gmail.com (C.C.)

3 Department of Medical Oncology, The Oncology Institute "Prof. Dr. Ion Chiricuta", Cluj-Napoca 400015, Romania

4 Department of Molecular Biology and Biotechnology, “Babes-Bolyai” University, Cluj-Napoca 400006, Romania

5 5th Department of Internal Medicine, University of Medicine and Pharmacy "Iuliu Hatieganu", Cluj-Napoca 400006, Romania; roberta786@yahoo.com

6 Department of Gastroenterology, Wilhelmina Hospital Assen, Europaweg-Zuid 1, 9401 RK Assen, The Netherlands

7 Department of Surgery, Municipal Hospital, University of Medicine and Pharmacy "Iuliu Hatieganu”, Cluj-Napoca 400139, Romania; mihai.stefan.muresan@gmail.com

8 11th Department of Oncological Surgery and Gynecological Oncology, University of Medicine and Pharmacy “Iuliu Hatieganu”, Cluj-Napoca 400015, Romania; cosminlisencu@yahoo.com (C.L.); airimie@umfcluj.ro (A.I.)

9 Department of Surgery, The Oncology Institute "Prof. Dr. Ion Chiricuta", Cluj-Napoca 400015, Romania

* Correspondence: obalacescu@yahoo.com

+ All authors contributed equally to this work.

Received: 27 October 2018; Accepted: 20 November 2018; Published: 22 November 2018

\begin{abstract}
Colorectal cancer (CRC) is one of the most commonly diagnosed malignancies with a high incidence and mortality rate. An essential challenge in colorectal cancer management is to identify new prognostic factors that could better estimate the evolution and treatment responses of this disease. Considering their role in cancer development, progression and metastasis, miRNAs have become an important class of molecules suitable for cancer biomarkers discovery. We performed a systematic search of studies investigating the role of miRNAs in colorectal progression and liver metastasis published until October 2018. In this review, we present up-to-date information regarding the specific microRNAs involved in CRC development, considering their roles in alteration of Wnt/ $\beta$ catenin, EGFR, TGF $\beta$ and TP53 signaling pathways. We also emphasize the role of miRNAs in controlling the epithelial-mesenchymal transition of CRC cells, a process responsible for liver metastasis in a circulating tumor cell-dependent manner. Furthermore, we discuss the role of miRNAs transported by CRC-derived exosomes in mediating liver metastases, by preparing the secondary pre-metastatic niche and in inducing liver carcinogenesis in a Dicer-dependent manner.
\end{abstract}

Keywords: miRNAs; colorectal cancer; exosomes; liver; metastases 


\section{Introduction}

Colorectal cancer (CRC) is the third most frequently diagnosed cancer worldwide, with an annual incidence of 1.4 million new cases and 694,000 deaths [1]. About $15 \%$ of CRCs are diagnosed in metastatic stages (stage IV), with an average survival rate of 2.5 years. Moreover, about $50 \%$ of patients that have a low TNM stage at diagnosis will eventually develop metastasis, mostly localized in the liver [2]. During the last decade, the clinical outcome of patients with metastatic CRC has improved due to the development of new chemotherapeutic drugs and targeted therapies. Today, the median overall survival for patients with metastatic disease is about 30 months, time that has doubled over the past 20 years [3].

Despite the current screening methods and prognosis factors (TNM stage, age, tumor differentiation grade, vessel invasion, performance status and tumoral markers according to the National Comprehensive Cancer Network (NCCN) guidelines), there are still a great number of patients that are experiencing therapeutic failure and metastasis [4]. Therefore, an important task in CRC management is to identify new prognostic factors that could help in selecting patients who could benefit from adjuvant therapies or from intensive screening for disease recurrence and metastasis.

After their discovery, micro-RNAs (miRNAs) have been shown to have important implications in cancer biology. Increasing evidence highlights that deregulated miRNAs' expression has a functional role in the progression and metastasis of CRC, acting either as tumor suppressors or oncogenes to regulate expression of their specific mRNA targets. Due to their high stability, miRNAs were considered and investigated as a new class of valuable biomarkers [5].

We will present herein up-to-date information about the specific miRNAs involved in CRC progression and liver metastasis and how these miRNAs control the epithelial-mesenchymal transition (EMT) of CRC cells, a process responsible for liver metastasis in a circulating tumor cell-dependent manner. We also emphasize the role of miRNAs transported by CRC-derived exosomes in mediating liver metastases, by preparing the secondary pre-metastatic niche and in inducing liver carcinogenesis in a Dicer-dependent manner.

\section{Selection of the Studies to Review}

We performed a systematic search of studies profiling the miRNAs involved in colorectal progression and liver metastasis, published until October 2018. Four PubMed string searches (Figure 1) were used for this aim; in the first search we identified the miRNAs involved in CRC progression and metastasis, considering their roles in alteration of Wnt/ $\beta$ catenin, EGFR, TGF $\beta$ and TP53 signaling pathways; in the second search we selected the miRNAs involved in the EMT, an important step in CRC metastasis; in the third, we identified the specific miRNAs transported by tumor-delivered exosomes (miRNA-TEX) released by CRC, which support the liver metastasis by preparing the secondary pre-metastatic niche, inducing pro-inflammation and immunosuppression; in the fourth, we found out the overlapping between miRNAs-TEX and miRNAs involved in promoting the hepatocellular carcinoma, in a Dicer-dependent manner. 


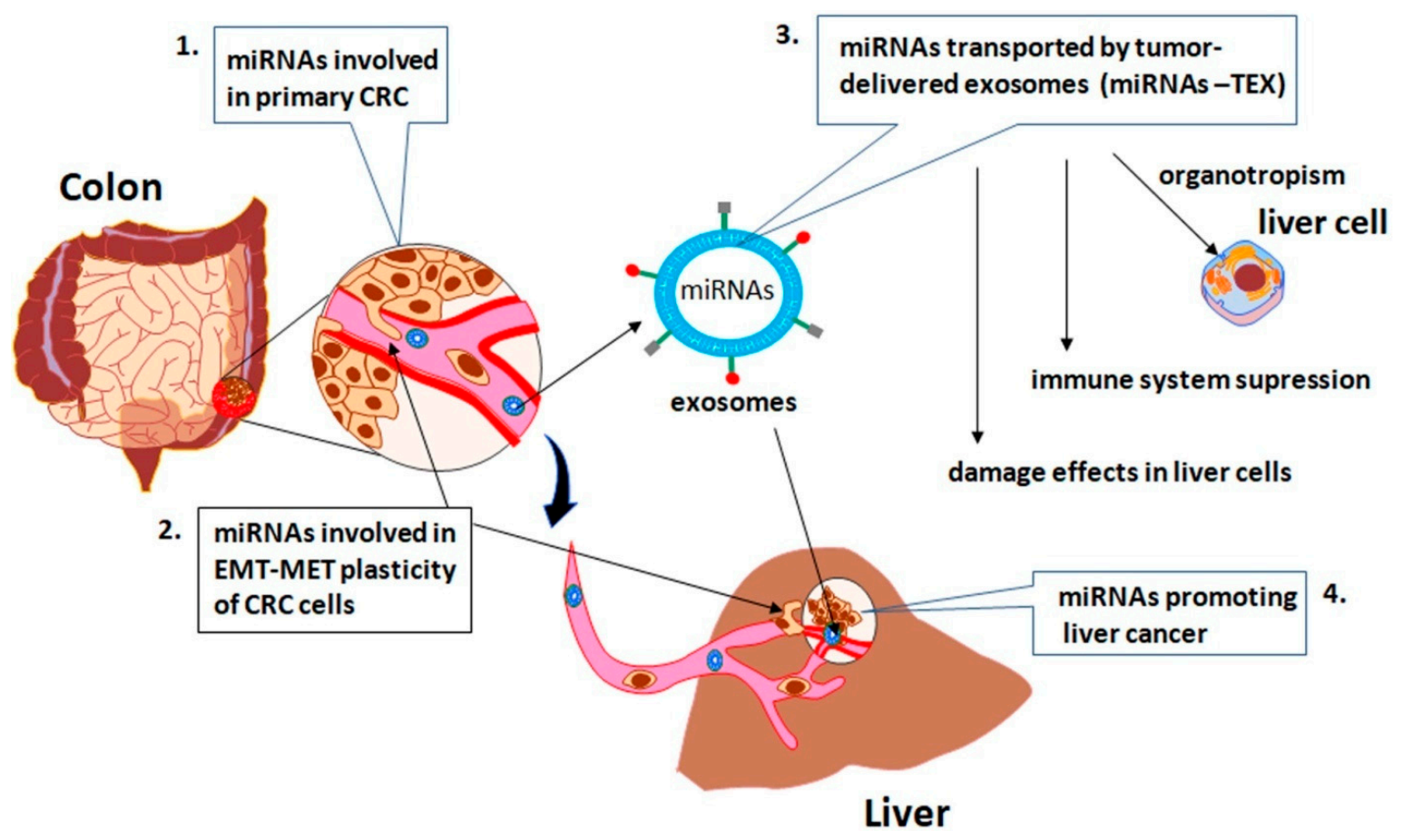

Figure 1. The PubMed string searches used to identify the specific miRNAs involved in colorectal cancer (CRC) development and progression as well as in liver metastasis.

\section{The Role of the Tumor Microenvironment in CRC Development and Progression}

In 2000, Hanahan and Weinberg [6] stated that there are "six essential alterations that collectively dictate malignant growth: self-sufficiency in growth signals, insensitivity to growth-inhibitory (antigrowth) signals, evasion of programmed cell death (apoptosis), limitless replicative potential, sustained angiogenesis and tissue invasion and metastasis". A decade later, when tumors were recognized as organs, compared to what was previously accepted as solitary masses of proliferating cells, an enhancement of these cancer hallmarks was provided. Thus, reprogramming energy metabolism and evading immune response became the newest hallmarks of cancers while tumor microenvironment (TME) has been proved to play a substantial role in tumor progression and metastasis [7]. A TME represents a very complex network between tumor cells and stromal, endothelial and immune cells, which substantially contributes to the validation of an aggressive tumor phenotype [8]. Moreover, the presence of inflammatory cells and inflammatory mediators such as chemokines and cytokines related to TME facilitates tumor progression, including CRC [9]. Besides that, TME facilitates CRC progression by maintaining a paracrine cross-talk signaling between tumor resident adipocytes that represent a fuel rich source of energy and cancer cells demanding energy for their rapid proliferation [10].

Nowadays, it is largely accepted that CRC occurs from an adenoma-carcinoma transition and implies genetic and epigenetic events, supported by TME [11]. The genetic and epigenetic studies in CRC have provided a lot of data about the mutational status and alteration of gene expression [12]. So far, a plethora of papers have broadly presented all these alterations that lead to "oncogene addiction" by activating several key oncogenes (e.g., KRAS, EGFR, MYC, ERBB2, etc.) or inactivating tumor suppressor genes (e.g., TP53, PTEN, WNT, SMAD2, SMAD4, etc.) and DNA repair genes (e.g., bMSH2, $b M L H 1, b P M S 1, b P M S 2$ and MSH6) [11,13,14].

Colorectal carcinogenesis is also mediated by epigenetic alterations, including changes in the DNA methylation status, both by global hypo-methylation and promoter hyper-methylation. Global hypomethylation decreased by $10-40 \%$ in CRC compared to normal colonic tissue, being associated with genomic instability, while promoter hyper-methylation leads to repression of several tumor suppressor genes and their specific pathways (e.g., TP53, PI3K/PTEN/AKT / mTOR, TGFb/SMAD) [15]. 
Furthermore, non-coding RNAs, especially miRNAs, play important roles in maintaining the physiology of normal colonic cells, while alteration of their levels contributes to CRC development, progression and metastasis, as well as drug resistance and tumor relapse [16]. Moreover, recent evidence indicates that miRNAs are involved in both direct cell-to-cell signaling and paracrine signaling between tumor cells and TME components as secreted molecules in microvesicles or exosomes [17].

\section{A Brief Overview of miRNAs}

Micro-RNA (miRNA, miR) represent the most studied class of non-coding RNAs, being responsible for negative modulating of up to $60 \%$ of protein-coding genes expression [18]. One of the most important features of miRNAs consists of their multi-target potential, such as a single miRNA can target up to 200 mRNAs, while different miRNAs can modulate the same mRNA target [19]. The biogenesis of miRNAs has been extensively presented before [20]. Shortly, the biogenesis of miRNA starts in the nucleus, with transcription of a long hairpin transcript (pri-miRNA) of hundreds or thousands of nucleotides. Further, by an enzymatic process coordinated by RNA polymerase III Drosha and DGCR8 (DiGeorge syndrome critical region 8) pri-miRNA is reduced to a smaller transcript of about 70 nucleotides, called pre-miRNA. After it is exported in the cytoplasm by nuclear receptor exportin 5, pre-miRNA is firstly reduced by Dicer complex to a mature miRNA duplex of about 22 nucleotides lengths and then to a single-stranded mature miRNA. Further, mature miRNA-loaded AGO2 and RNA-induced silencing complex (RISC) will function as a guide to target specific mRNA transcripts by sequence complementarity, usually in the $3^{\prime}$ untranslated region (UTR), leading to translational repression or mRNA degradation (Figure 2).

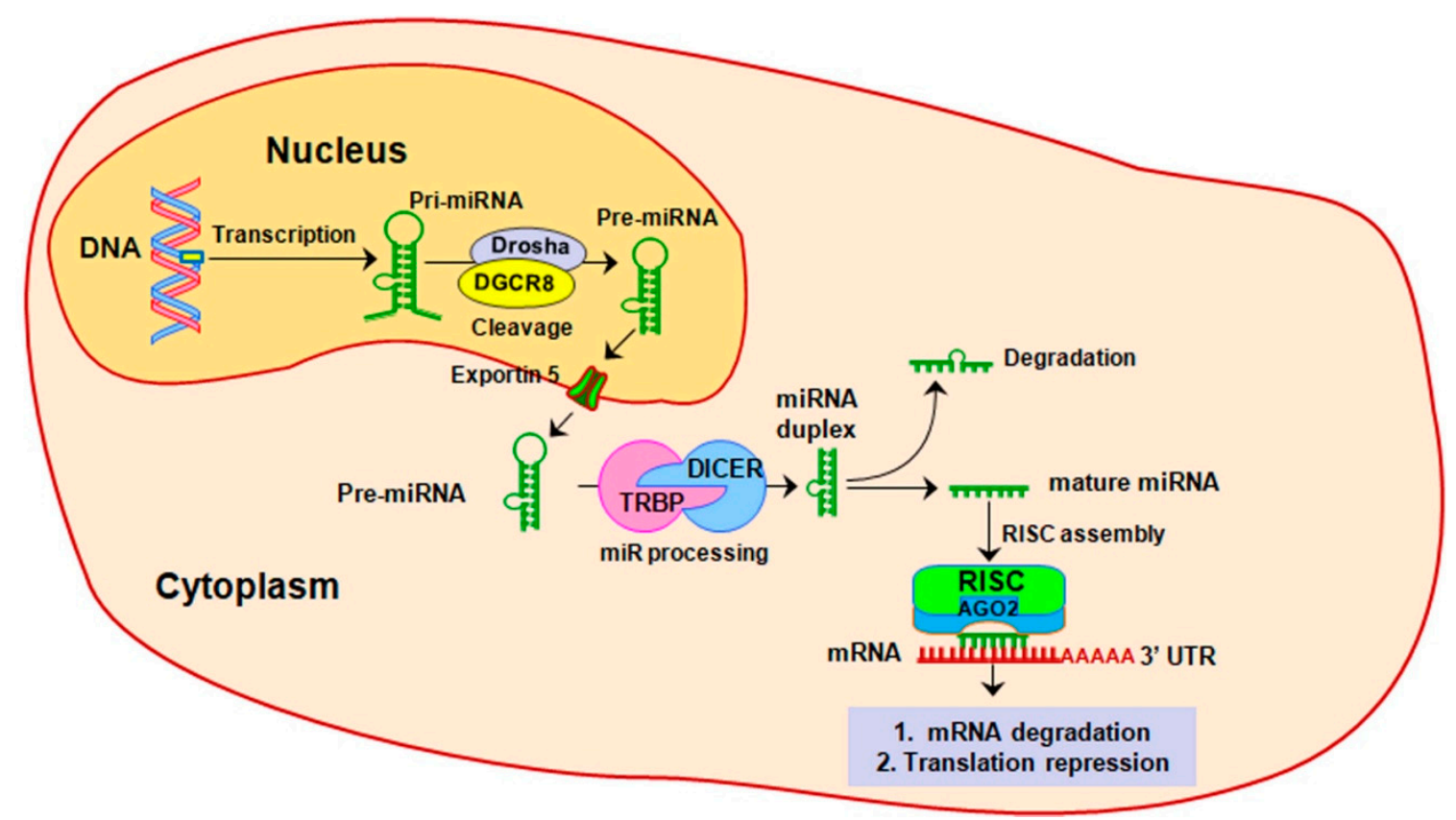

Figure 2. MiRNA biogenesis. MiRNA biogenesis starts in the nucleus with a long hairpin transcript called pri-miRNA that is further processed to a smaller transcript of 70 nucleotides. After is exported in the cytoplasm, pre-miRNA is enzymatically processed to single-strand mature miRNA of about 21-23 nucleotides. When it is incorporated in the enzymatically machinery called the RNA-induced silencing complex (RISC), mature miRNA guide the RISC to silence the specific mRNA transcripts, either by their degradation of by translation repression. 
Croce's group [21] demonstrated for the first time that miRNAs alteration is responsible for cancer development and also they reinforced the hypothesis that miRNA acts as the negative regulators of their target mRNAs [22]. Immediately afterward a worldwide research effort has been taken to identify and characterize new cancer-related miRNAs. Currently, the latest data from miRNA database miRBase Release 22 (http: / / www.mirbase.org/) include 2815 mature human miRNAs. Nevertheless, a big challenge consists of identification of the cancer-specific mechanisms altered by miRNA modulation. Consequently, a large number of miRNA:mRNA target prediction tools, included different algorithms, have been developed. The question about which is the best algorithm does not yet have a precise answer, although TargetScan represents one of the most considered options [23]. However, accuracy prediction of the miRNA:mRNA interaction is still challenging and the regulatory function of each miRNA should to be experimentally validated, specific for each pathology. The functionality of oncogenes and tumor suppressor genes in cancer is tightly controlled by two classes of miRNAs, called tumor-suppressor miRNAs (TS-miRNAs, TS-miRs) and oncomiRs, respectively. Genetic and epigenetic alterations that underlie cancer development lead to "loss of function" or inactivation of TS-miRs and "gain of function" or over-activation of oncomiRs. As a result, the oncogenes, that are the targets of TS-miR, become overexpressed, while the tumor suppressor genes are inhibited by the overexpression of the oncomiRs [24].

\section{The Role of miRNAs in CRC Progression and Metastasis}

The first association of miRNAs with colon cancer was described by Michael et al. [25] fifteen years ago when they reported decreased miR-143 and miR-145 expression in colon cancer when compared to normal colon tissue. Since then, many studies have been conducted to investigate the miRNAs involvement in colorectal carcinogenesis. Considering the evolutionary progression of CRC from adenomas, in-depth understanding of the miRNAs-modulated molecular mechanisms in CRC has become a major challenge [26,27]. It has been shown that alterations in Wnt/ $\beta$ catenin, EGFR, TGF $\beta$ and TP53 signaling pathways result in survival, proliferation, invasion and metastasis of CRC [28,29]. Therefore, many studies have focused on these pathways, to establish the miRNAs:mRNA interaction networks, in order to complete the molecular puzzle that underlines the CRC development, progression and metastasis. Adenomatous polyposis coli $(A P C)$ is an important tumor suppressor gene with an inhibitory function on Wnt/B-catenin signaling. When mutated, as happens in $90 \%$ of CRC, APC loses its inhibitory function, leading to tumorigenesis, invasion and metastasis. An increasing number of studies have identified specific miRNAs that lead to alteration of APC/Wnt/B-catenin signaling, either by direct suppression of $A P C$ (eg miR135a/b, miR-494, miR-19a) and aberrant activation of the Wnt pathway (eg miR-21, miR-155, miR-103a, miR-1827, miR-145, miR-34a), or indirectly, targeting other members of these pathways (miR-150, miR-224, miR-146a, miR-574-5p). An up-to-date list of oncomiRs and tumor suppressor miRNAs (TS-miRNAs), and their targets involved in the alteration of Wnt/B-catenin signaling in CRC is presented in Table 1. 
Table 1. MiRNAs and their mRNA targets associated with the development, progression and metastasis of CRC.

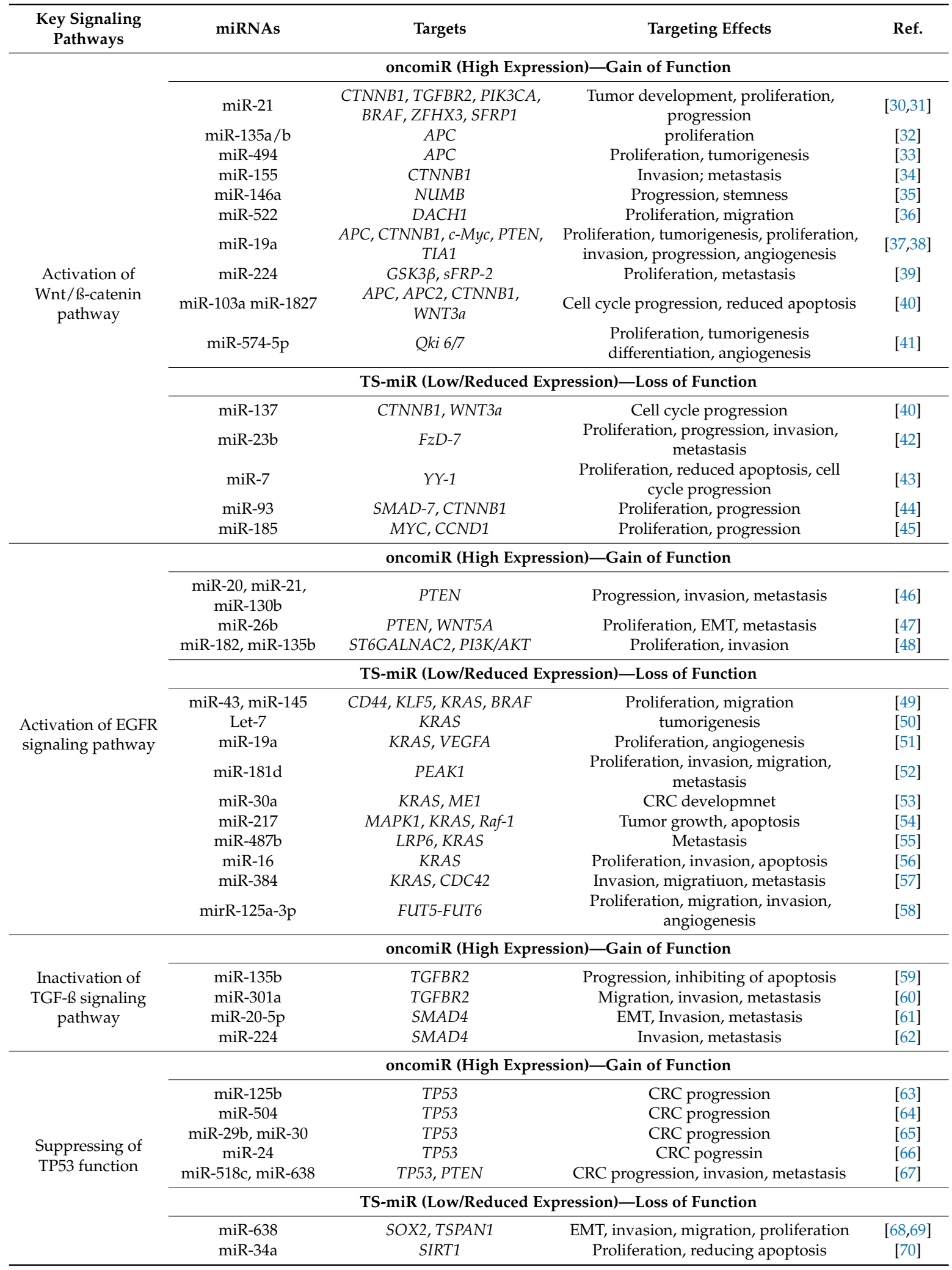


The EGFR signaling pathway has a critical role in normal embryogenesis, mediating cell proliferation, differentiation, migration and apoptosis. The gain of function of EGFR by genetic alterations leads to cancer development. About $50 \%$ of CRC present EGFR gene amplification and mutational activation of KRAS and BRAF downstream mediators [71]. Recent studies have reported that aberrant activation of oncogenic EGFR pathway can be due to TS-miRNAs loss of function. Two of the most important TS-miRNAs involved in the EGFR pathway are miR-143 and miR-145, whose combined action decreases proliferation and migration by targeting several members of the EGFR pathway, including KRAS and BRAF [49]. Loss of function of let-7a was associated with high levels of KRAS and c-MYC and colon tumorigenesis [72], while the let-7 KRAS rs712 polymorphism was correlated with increased colorectal cancer risk [50]. Recent evidence has confirmed that miR-19a can inhibit CRC angiogenesis by targeting KRAS and VEGFA [51] and that miR-181d reduces cell proliferation, migration and invasion by triggering PEAK1, a downstream regulator in EGFR/KRAS pathway [52]. On the other hand, activation of the KRAS pathway can trigger and upregulate some oncomiRs, such as miR-210 and miR-181a with a role in CRC development and progression [73] or miR200c that has a pivotal role in CRC aggressiveness and metastasis [74].

The AKT-PI3K-mTOR pathway represents the second signaling hub of the EGFR pathway, being amplified in about 15-20\% CRC [75]. Amplification of the AKT-PIK3K-PTEN pathway is mediated both by the loss of function of TS-miRs, such as miR-126, miR-497 and miR-1, or by upregulation of several oncomiRs including miR-21, miR-19 and miR-96 [76]. More data about miRNAs involved in the EGFR signaling pathway in CRC developing and progression are presented in Table 1, section EGFR signaling pathway.

TGF- $B$ signaling has a dual function in colorectal carcinogenesis. It is a tumor suppressor in early stages of CRC development, but acts as a tumor promoter in advanced stages of CRC. The tumorigenic activity of TGF- $ß$ signaling is due to several up- and downstream defects that enhance multiple oncogenic pathways leading to increased angiogenesis, evasion of the immune system, evading apoptosis, EMT and metastasis [77]. Mutational alterations of TGFBR2, the key component that initiates signaling in the TGF- $\beta$ pathway, were identified in about $30 \%$ of CRCs. However, recent evidence indicates that many miRNAs are involved in TGFBR2 regulation (Table 1). Several of them, including miR-301a and miR-135b, induce proliferation, migration and invasion in CRC cells through negative regulation of TGFBR2 expression [59,60]. Also by negative regulation of $S M A D 4$, a mediator of the TGF- $\beta$ pathway, miR-20-5p and mir-224, induces EMT, invasion and metastasis of CRC cells $[61,62]$.

TP53, "the guardian of the genome", is a tumor suppressor gene with multiple roles in maintaining the cellular physiology under many stress conditions, including cancer [78]. Almost 50\% of CRCs present inactivation of TP53 by deletions or point mutations [79]. Albeit TP53 can affect transcription and maturation of many miRNAs, both by transactivation of tumor-suppressor miRNAs and by repression of oncogenic miRNAs, there is increasing evidence that TP53 expression is also under the tight control of miRNAs [80]. Translational repression of TP53 in CRC is controlled by several miRNAs including miR-125b, miR-504, miR-25, miR-30d and miR-638. Previous data have demonstrated that miR-125b is an independent prognostic factor in CRC, its high expression being associated with poor prognosis [63], while mir-504 was shown to have a role in the negative regulation of TP53 in several cancers, including CRC [64]. Moreover, miR-25b and miR-30 were found to reduce apoptosis by negative regulation of both gene expression and protein level of TP53 [65]. Interestingly, miR-518c and miR-638 can target and inactivate both TP53 and PTEN genes [67]. However, several studies have reported that miR-638 can also function as tumor suppressor miRNAs, its loss of function leading to proliferation, EMT, migration and invasion of CRC by upregulating SOX2 and TSPAN1 proteins $[68,69]$. Another study has reported that TP53 can indirectly be repressed by SIRT1, a target of tumor suppressor miR-34a [70]. 
However, miRNAs-mRNAs networks in CRC are more complex in the more specific case of CRC metastasis. MiRNAs can control the EMT underlying the movement of the colorectal circulating tumor cells (CTCs). By their encapsulation in exosomes, miRNAs provide support in preparing the liver metastatic niche, suppressing of the immune system, and modulating the liver phenotype in a Dicer-dependent manner.

\section{The Role of miRNAs in CRC Metastasis, by Modulation of EMT}

Understanding the molecular mechanisms underlying CRC metastasis is crucial for improving the treatment strategies for this pathology and consequently, to increase the patients' survival rate. Although the miRNAs-mediated mechanisms in colorectal carcinogenesis are quite well understood, those responsible for metastasis are not yet elucidated.

An important feature of cancer cells that lead to invasion and metastasis consists in changing their epithelial characteristics to mesenchymal ones, a process known as the epithelial to mesenchymal transition (EMT). During EMT, cancer cells undergo several processes that modify their phenotype, leading to cell motility, the acquisition of stemness properties, inhibition of apoptosis and immunosuppression. Epithelial to mesenchymal transition is characterized by dissolution of epithelial tight cell junctions by downregulation of several specific genes that encode proteins like E-cadherin (CDH1) and claudins, and by promoting the mesenchymal adhesion by activating several protein-coding genes, as the ones for vimentin (VIM), N-cadherin (NCAD) and fibronectin (FN1). Stimuli from TME such as inflammatory cytokines and growth factors have a significant role in tumor evolution, by abnormally regulating the EMT of cancer cells [81]. The EMT modulation requires a complex network of cooperation including many regulators and inducer molecules [82].

The main regulators of EMT are represented by three families of activating transcription factors: SNAIL, ZEB and TWIST. However, accumulating evidence has shown that two other families of transcription factors, PROX1 and FOX, are involved in EMT of CRC. Nevertheless, the induction of EMT by members of these families of transcription factors involves multiple pathways, tightly coordinated by miRNAs (Table 2).

Table 2. MiRNAs and their mRNA targets associated with regulation and induction of epithelial to mesenchymal transition (EMT) and mesenchymal-epithelial transition (MET), supporting CRC invasion and metastasis.

\begin{tabular}{|c|c|c|c|c|}
\hline Key Signaling & miRNAs & Targets & Function & Ref. \\
\hline \multirow{9}{*}{$\begin{array}{l}\text { Regulation of } \\
\text { EMT }\end{array}$} & \multicolumn{4}{|c|}{ oncomiR (High Expression)—Gain of Function } \\
\hline & miR-675-5p & SNAIL & EMT, invasion, metastasis & [83] \\
\hline & \multicolumn{4}{|c|}{ TS-miR (Low/Reduced Expression)—Loss of Function } \\
\hline & $\mathrm{miR}-34 \mathrm{a} / \mathrm{b} / \mathrm{c}$ & $\begin{array}{l}\text { SNAIL, SLYG, ZEB1, BIM1, } \\
\text { CD44, CD133, c-MYC }\end{array}$ & EMT, invasion, metastasis, MET & {$[84,85]$} \\
\hline & miR-375 & $\begin{array}{l}\text { SP1, MMP2, SNAIL, CDH1, } \\
\text { VIM, CDH2, CTNNB1 }\end{array}$ & EMT, invasion, metastasis & {$[86]$} \\
\hline & miR-374 & $\begin{array}{c}\text { CCND1, ZEB1, CDH2 VIM, } \\
\text { SLUG, SNAIL }\end{array}$ & $\begin{array}{l}\text { EMT, proliferation, invasion, } \\
\text { migration, liver metastasis }\end{array}$ & [87] \\
\hline & miR-200c & ZEB1, ETS1, FLT1, ASCL2 & $\begin{array}{l}\text { EMT-MET plasticity, invasion, } \\
\text { migration, liver metastasis }\end{array}$ & {$[88,89]$} \\
\hline & $\operatorname{miR}-429$ & ONECUT2, ZEB1, ZEB2 & EMT, invasion, migration & [90] \\
\hline & $\begin{array}{l}\text { miR-335, miR-132, } \\
\text { miR-192 }\end{array}$ & ZEB2 & EMT, Invasion, metastasis & {$[91-93]$} \\
\hline
\end{tabular}


Table 2. Cont.

\begin{tabular}{|c|c|c|c|c|}
\hline Key Signaling & miRNAs & Targets & Function & Ref. \\
\hline \multirow{14}{*}{$\begin{array}{l}\text { Inducing of } \\
\text { EMT }\end{array}$} & \multicolumn{4}{|c|}{ oncomiR (High Expression)-Gain of Function } \\
\hline & miR-20a & SMAD4, MMP2, MMP9 & EMT, migration, metastasis & {$[94,95]$} \\
\hline & $\operatorname{miR}-4775$ & $S M A D 7 / T G F-\beta$ & EMT, invasion, metastasis & [96] \\
\hline & miR-1269 & SMAD7, HOXD10 & EMT, invasion, metastasis & [97] \\
\hline & miR-21 & NRF2, SMAD7 & EMT, invasion, metastasis & [98] \\
\hline & miR-150 & CREB & EMT, invasion, migration & [99] \\
\hline & miR-194 & MMP2 & EMT, invasion, migration & [100] \\
\hline & \multicolumn{4}{|c|}{ TS-miR (Low/Reduced Expression)—LLoss of Function } \\
\hline & miR-320c & SOX4, FOXM1, FOXQ1 & $\begin{array}{l}\text { EMT, proliferation, migration, } \\
\text { tumorigenesis }\end{array}$ & [101] \\
\hline & miR-187 & SOX4, NT5E, PTK6 & EMT, invasion, metastasis & [102] \\
\hline & $\operatorname{miR}-34 a$ & $\begin{array}{l}\text { CTNNB1, c-Met ZEB1, } \\
\text { ZEB2, SNAIL }\end{array}$ & Progression, EMT, liver metastasis & {$[103,104]$} \\
\hline & $\operatorname{miR}-145$ & $\begin{array}{l}\text { SIP1, CTNNB1, TCF4, } \\
\text { VIM, SNAIL }\end{array}$ & $\begin{array}{l}\text { Proliferation, migration, EMT, } \\
\text { invasion, metastasis }\end{array}$ & [105] \\
\hline & $\operatorname{miR}-29 b$ & $\begin{array}{l}\text { BCL9L, TCF7L2, } \\
\text { SNAI1, PGRN }\end{array}$ & $\begin{array}{l}\text { Cell growth, EMT, angiogenesis, } \\
\text { invasion, migration }\end{array}$ & {$[106,107]$} \\
\hline & Let-7c & MMP11 & Cell migration and invasion & [108] \\
\hline
\end{tabular}

MiR-34 family (miR-34a/b/c), directly regulated by TP53, is involved in preventing TGF $\beta$-induced EMT by suppressing SNAIL, SLUG and ZEB1 transcription factors, as well as the stemness factors BMI1, $C D 44, C D 133$, or $c-M Y C$. Conversely, SNAIL and ZEB1 repress miR-34a/b/c expression, promoting EMT. However, the loss of function of TP53 and/or miR-34a/b/c, found in many cancers, represents an important molecular alteration facilitating cancer metastasis [84]. Epithelial to mesenchymal transition activation by SNAIL in CRC directly induces ZNF281 transcription, leading to repression of $\mathrm{miR}-34 \mathrm{a} / \mathrm{b} / \mathrm{c}$ that contributes to CRC metastasis [85].

In a recent study [86], miR-375 was proved to regulate MMP2 and several EMT-associated genes, including SNAIL. When it is downregulated, miR-375 leads to proliferation, invasion and migration of colorectal cancer cells. MiR-374 represents another tumor suppressor, whose loss of function in CRC induces the activation of the PIK3/AKT pathway, promoting proliferation, invasion, migration and intrahepatic metastasis. Transcription factors SNAIL, SLUG and ZEB1 as well as NCAD and VIM are among the targets of miR-374, all of which being significantly upregulated by miR-374 inhibition [87]. MiR-200c and miR-429, two members of the miR-200 family, are predominately involved in the regulation of $Z E B$ transcription factors in CRC cells. Induction of miR-200c leads to inactivation of EMT by suppressing ZEB1 expression which results in reduced invasion and migration of CRC cells [88]. MiR-429 could reverse TGF $\beta$-induced EMT by targeting ONECUT2, and thus, inhibiting cell migration and invasion. However, miR-429 is significantly downregulated in CRC [90]. On the other hand, activation of miR-200 cluster by loss of function of ASCL2, a downstream target of WNT signaling, leads to inhibition of ZEB and SNAIL families of transcription factors, and consequently, to the regulation of the plasticity from EMT to mesenchymal-epithelial transition (MET) [89]. Downregulation of other tumor suppressors, mainly miR-335, miR-132 and miR-192 was related to invasion and metastasis of CRC by increasing expression of their ZEB2 target gene [91-93]. In hypoxic conditions, miR-675-5p overexpression can regulate hypoxia-induced EMT driven by HIF1 $\alpha$, through increasing SNAIL transcription by both inhibiting the SNAIL's repressor DDB2 and stabilizing the activity of the transcription factor $H I F 1 \alpha$ [83].

Although a few papers have described several miRNAs targeting PROX1, none of them has focused on CRC. However, the role of PROX1 inducing EMT in CRC was previously pointed out. PROX1 can promote EMT by inhibiting CDH1 expression via binding to the promoter of pre-miR-9-2 and triggering its expression [109]. On the other hand, two members of the FOX family of transcription factors, FOXQ1 and FOXM1, have been recently identified as targets of miR-320c, as part of the EMT induction process. Vishnubalaji R et al. [101] reported low levels of miR-320 in CRC compared to 
normal tissues and an inverse correlation with SOX4, FOXM1 and FOXQ1 expression, leading to decreased $C D H 1$ expression.

The main inducers of EMT in CRC are TGF- $\$$ and Wnt/ $ß$-catenin pathways but TMPRSS4, FMNL2, GDF15, NRP2 or TUSC3 were also linked to EMT in CRC [82]. TGF-3-induced EMT in CRC is related to both $S M A D$-dependent and -independent mechanisms and partly influenced by alteration of miRNAs expression. The role of SMAD4 in EMT has been extensively studied. Previous studies have demonstrated that normal levels of SMAD4 maintain the epithelial phenotype while inactivation of SMAD4 leads to invasion and metastasis. Downregulation of mir-187, a downstream effector of the TGF- $\beta$ pathway with a role in EMT prevention, leads to increased expression of SOX4, NT5E and PTK6, known as important upstream regulators of the SMAD pathway. Loss of function of miR-187 was tightly correlated with CRC metastasis and a reserved prognosis [102]. On the other hand, over-expression of miR-20a induces EMT, promoting metastasis of CRC via suppression of $S M A D 4$ expression [94]. Moreover, the TGF $\beta$-induced EMT can be initiated by suppressing the SMAD inhibitors, such as SMAD7. Thereby, miR-4775, miR-1269 and miR-21 promote CRC metastasis in a SMAD7/TGF $\beta$ signaling-dependent manner [96-98]. MiR-150, the most expressed miRNA induced by Wnt/ -catenin pathway, enhances the EMT in CRC by targeting the cAMP response element-binding protein (CREB) signaling pathway [99].

Although Wnt-induced EMT in CRC is mostly activated by canonical Wnt/ $\$$-catenin signaling, there is evidence that also non-canonical Wnt signaling is involved in EMT. The Wnt-induced EMT could be activated by suppressing the negative regulators of several transcription factors. Accordingly, loss of function of the tumor-suppressors miR-34a, miR-145 and miR-29b leads to the induction of EMT. Mir-34 is a suppressor of the $B$-catenin pathway and EMT $[85,103]$ but its inhibition by methylation leads to cancer progression and metastasis [104]. Likewise, the loss of function of miR-145 was inverse correlated with the overexpression of several genes involved in EMT, such as CTNNB1, VIM and $S N A I$, and the downregulation of CDH1 expression in SW480 cells [105]. The regulation of EMT in colon cancer cells via miR-29b involves blocking of various $\beta$-catenin target genes, by suppressing the coactivators of $\beta$-catenin such as TCF7L2, SNAIL and BCL9L [106]. Moreover, recent data has shown that miR-29b-3p modulated by $\operatorname{lncRNAH19}$ can promote the EMT in CRC by directly binding and targeting the progranulin (PGRN) [107].

Recent evidence has shown that circulating tumor cells (CTCs) from CRC are responsible for liver metastasis [110], while the EMT-MET plasticity of CTCs is considered an important hallmark of metastasis [111]. Both the detachment of CTCs from the primary CRC and their attachment in the liver are closely mediated by miRNA. Circulating tumor cells detachment is facilitated by increasing the activity of the matrix metalloproteinases $(M M P s)$ or by inhibiting the tissue inhibitors of metalloproteinase (TIMPs). On this regard, miR-194 can promote EMT-mediated metastasis of CRC by MMP2 activation [100], while miR-20a promotes CRC metastasis by inhibiting TIMP2, that leads to increasing of MMP2 and MMP9 enzymatic activity [95]. Moreover, by destabilizing MMP11 mRNA, let-7c plays a role as a metastasis suppressor, in addition to its tumor growth suppressor activity [108]. While CTCs are responsible for tumor metastasis, miRNAs-TEX are responsible for preparing the secondary metastatic niche.

\section{The Role of miRNAs-TEX in Sustaining the CRC Liver Metastasis}

The occurrence of liver metastases from CRC represents a multistep process that involves EMT-MET plasticity of colorectal CTCs, local remodeling of the liver microenvironment and immunosuppression. Generally, these processes are strongly mediated by miRNAs-TEX released by CRC.

Exosomes are small extracellular vesicles of about $30-100 \mathrm{~nm}$ surrounded by a lipid bilayer, derived from multivesicular bodies (MVBs) generated within the cell's endosomal system. They are secreted by multiple cell types, including tumor cells, and can be detected in most body fluids such as breast milk, urine, saliva, semen and blood, as well as in supernatants of cultured cells. Exosomes 
can modulate the phenotype of the cells they bind to by transferring them to their cargo content, either in a paracrine or endocrine manner [112]. Preparing the secondary pre-metastatic niche or remodeling the liver microenvironment is a mandatory condition to sustain liver metastasis. Exosomes released by CRC can transfer bioactive molecules including nucleic acids (DNA, mRNA, miRNA, lncRNA, circRNA etc), proteins (transcription factors, receptors, enzymes, etc), and lipids to the liver cells, modulating their phenotype [113]. One of the most important features of TEXs is that they can determine the organotropism and predict organ-specific metastasis due to their distinct integrin expression patterns. Integrins bind to specific receptors found on target cells, preparing the secondary pre-metastatic niche by inducing the pro-inflammatory signals through Src phosphorylation and S100 gene expression [114]. Two chemokine receptors, CXCR4 [115] and CCR6 [116] have been previously associated with CRC metastasis to the liver (Figure 3). Moreover, previous data exploring the characteristics of the metastatic pattern of CRC has revealed that the liver is the main metastatic site of CRC, while lungs, bones and the brain are less common [117].

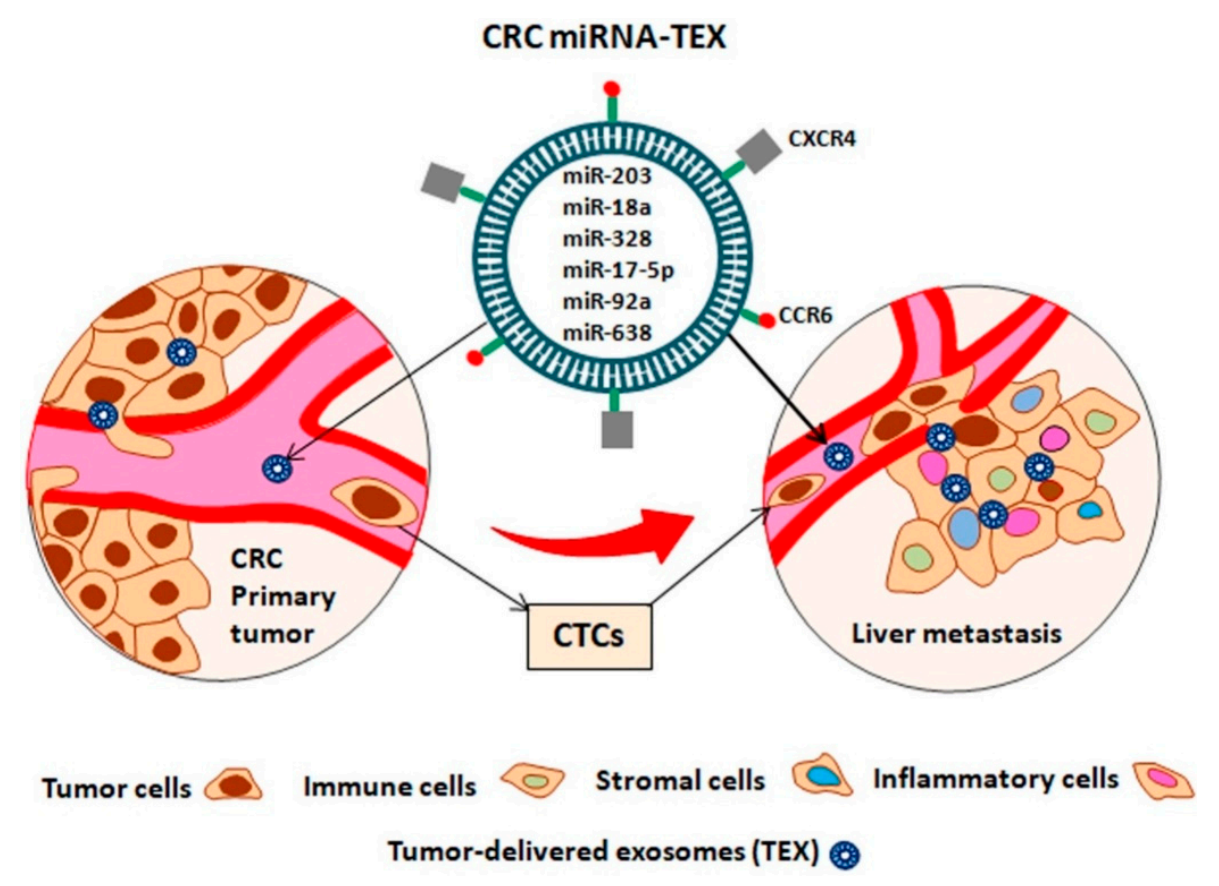

Figure 3. CRC metastasis in the liver through CRC circulating tumor cells (CTCs), mediated by miRNAs transported by CRC-delivered exosomes (miRNA-TEX). CXCR4 and CCR6 chemokine receptors are responsible for liver organotropism of miRNA-TEX, while the miRNAs released in the liver are responsible for preparing the secondary pre-metastatic niche by inducing the pro-inflammatory and pro-tumorigenic signals.

According to the existing data, miRNAs are the most studied exosomes-entrapped molecules that are involved in cancer development, progression and metastasis. Since 2010, when the functional role of miRNAs-TEX in gene expression regulation in recipient cells was demonstrated [118], their essential contribution to the hallmarks of cancer has been acknowledged [119]. However, the amounts of miRNAs that are incorporated into the exosomes released by different tumors remain to be elucidated. One hypothesis mentions that the abundance of miRNAs-TEX depends on the presence of their mRNA target transcripts in the cytoplasm of the donor cell. Therefore a presumptive mRNA-miRNA interaction in the donor cell could lead to low levels of that miRNA in the exosomes [112]. On the other hand, miRNAs sorting into exosomes could be conditioned by their posttranscriptional modifications, so that $3^{\prime}$ end adenylated miRNAs are preponderantly enriched in cells while $3^{\prime}$ end uridylated miRNAs are enriched in exosomes [120]. 
Wang et al. [121] demonstrated for the first time that exosomes play a pivotal role in colorectal cancer liver metastasis. Using nude mouse models, the authors demonstrated that exosomes derived from a highly liver metastatic CRC cell line (HT-29) can induce the same aggressive liver metastasis in the Caco-2 xenograft mouse model that usually has poor liver metastatic potential. The mechanisms by which HT-29-derived exosomes influence the liver metastasis of CRC involve increased CXCR4 expression in many types of stromal cells that contribute to the remodeling of the liver microenvironment and thereby to the development of the secondary pre-metastatic niche. Moreover, the treatment of Caco-2 cells line with HT-29-derived exosomes has led to increased migration of Caco-2 cells, highlighting the main role of exosomes in colorectal liver metastasis. Since then, several studies have identified miRNAs-TEX as relevant molecules in CRC liver metastasis.

Accordingly, exosomal miR-203 from CRC cells can sustain the formation of the premetastatic niche by promoting the differentiation of monocytes to M2-tumor-associated macrophages (TAMs) involved in liver metastasis of CRC patients [122].

Moreover, recent evidence has suggested that liver pre-metastatic niches could be promoted by exosomal miR-21 of CRC cells, through the miR-21-TLR7-IL6 axis [123]. Significantly increased levels of serum exosomal miR-6803-5p [124] and decreased levels of miR-548c-5p have been recently associated with poor survival and liver metastasis of CRC patients [125]. However, the molecular mechanisms by which both miR-6803-5p and miR-548c-5p influence CRC metastasis remain largely unknown. Likewise, new evidence has revealed that decreased levels of serum exosomal miR-638 are associated with an increased risk of liver metastasis [126]. Previous data demonstrated that miR-638 functions both as an oncomiR by targeting TP53 and PTEN [67] and as a tumor suppressor by inhibiting TSPAN1, in CRC [69]. Using a translational research model, including culture cells, mouse models and human samples, Fu et al. [127] have recently demonstrated that miR-17-5p and miR-92a-3p exosomal expression is related to CRC metastasis, but not to the CRC mutational type. The area under ROC curves (AUC) of these serum exosomal miRNAs was about 0.84 , while their combination leads to an AUC of 0.91 . Based on a very interesting hypothesis that tumor-draining vein could provide more homogeneous information than blood drawn from the peripheral vein (PV), Monzo et al. [128] demonstrated that CRC primary tumors release higher concentrations of miRNAs through the mesenteric vein (MV) than the PV. Accordingly, they observed that exosomal miR-328 was higher in the MV than in PV plasma of the patients developing liver metastasis, suggesting a possible role of miR-328 in the development of CRC liver metastasis. However, miRNAs loading into exosomes is not a passive process. Teng et al. [129] have recently demonstrated that the sorting of oncomiRs into exosomes is suppressed, while the sorting of TS-miRs into exosomes is increased. Furthermore, they found that exosomal TS-miR including miR-193a and miR-18a are significantly higher in patients with liver metastasis compared to CRC patients having no metastasis. Functional analysis demonstrated that miR-193a modulates CRC progression by CCDN1 and c-MYC expression via Caprin1, its direct target.

Quite interestingly, recent evidence has pointed out that miRNA-TEX released by breast cancer are directly involved in changing the normal cell phenotype into a tumor phenotype, promoting CTCs-independent metastasis, in a Dicer-dependent manner [130]. However, no data supporting this approach for CRC metastasis has been presented yet. Besides, previous data have mentioned the role of tumor-derived exosomes in the suppression of the immune system of the host [131]. Nevertheless, identifying miRNAs entrapped in exosomes released by colorectal tumors and involved in the suppression of the immune system during CRC metastasis remains a major challenge.

\section{The Role of CRC miRNAs-TEX in the Promotion of Hepatocellular Carcinoma}

The exosomes delivered by tumor cells contain both miRNAs and proteins/enzymes (Dicer, Argonaute 2 (Ago2) and TRB as well as the RISC Complex) used for miRNAs processing and silencing the mRNA targets of the recipient cells. Considering that miRNAs-TEX could modify the phenotype of the recipient cells, by modulating the cell transcriptome in a Dicer-dependent manner [130], we further 
analyzed the association of the CRC miRNAs-TEX mentioned above with the miRNA signature specific for the hepatocellular carcinogenesis (HCC) (Table 3).

Table 3. Common miRNAs identified both in exosomes-delivered by CRC cells and in the early diagnosis of hepatocellular carcinomas.

\begin{tabular}{|c|c|c|c|}
\hline CRC miRNAs-TEX & HCC Targets & Function & Ref. \\
\hline \multicolumn{4}{|c|}{ oncomiR } \\
\hline \multirow[t]{2}{*}{ Mir-21 } & BTG2 & Tumorigenesis & [132] \\
\hline & TSC1 & Tumorigenesis & [133] \\
\hline \multirow[t]{2}{*}{ Mir-18a } & $I R F 2, C B X 7$ & Cell proliferation & [134] \\
\hline & Dicer I & Migration and invasion & [135] \\
\hline miR-328 & PTPRJ & Tumor progression, motility & [136] \\
\hline miR-17-5p & P38, HSP27 & Proliferation and cell migration & [137] \\
\hline $\operatorname{mir}-92 a$ & FOXA2 & Inhibiting apoptosis, tumorigenesis & {$[138,139]$} \\
\hline \multicolumn{4}{|c|}{ TS-miR } \\
\hline miR-638 & SOX2 & EMT, development & [140] \\
\hline
\end{tabular}

MiR-21 is one of the most oncogenic miRNAs and its relationship with HCC has been already proved [141]. Thus, it can be speculated that the transfer of CRC miR-21-TEX into liver cells could contribute to liver metastasis. The tumor suppressor gene BTG2 represents one of the miR-21 targets, its negative correlation with miR-21 expression being related to hepatocarcinogenesis [132]. Recent data has revealed that miR-18a has an important role in promoting liver cancer, by targeting the tumor suppressor gene $T S C 1$, leading to downstream regulation of the mTOR signaling pathway [133]. More data pointed out that miR-18a is involved in liver cell proliferation by targeting IRF2 and CBX7 [134], as well as HCC cell migration and invasion, by inhibiting the Dicer I expression [135]. MiR-328 represents another oncomiR found into the exosomes released by CRC which would promote liver metastasis. Previous evidence highlighted the role of miR-328, as a crucial oncogene that targets and suppresses the PTPRJ gene, leading to an increased cellular motility in HCC [136]. Likewise, miR-17-5p, found increased in the exosomes of the metastatic CRC has an important role in liver cancer, promoting HCC cell proliferation and migration, by modulating the p38-HSP27 signaling pathway [137]. High levels of exosomal miR-92a were associated with CRC metastasis [127], but high levels of miR-92a in the liver cells have also been associated with HCC development [138]. Recent evidence has pointed out that FOXA2 represent a direct target of miR-92a, in HCC development and progression [139]. A very interesting observation is about miR-638, which plays a dual role in colorectal tumorigenesis, modulating invasion and metastasis of CRC. Low levels in exosomal miR-638 were associated with CRC metastasis, but low levels of miR-638 were also associated with invasion and EMT in HCC, by targeting SOX2 [140]. No data about the role of miR-548, iR-193 and miR-6803 in liver carcinogenesis has been reported yet.

\section{Clinical Implication of miRNAs as Reliable Biomarkers}

Considering their high stability in many types of biological samples [142,143], miRNAs have become important candidates for discovering new cancer biomarkers for CRC. Currently, a myriad of papers have presented the utility of serum miRNAs in CRC diagnosis, prognosis and treatment response. As an example, a set of six miRNAs including miR-21, let-7g, miR-31, miR-92a, miR-181b and miR-203 have been shown to be a reliable biomarker for CRC diagnosis with over $40 \%$ specificity and sensitivity compared to classical markers such as the carcinoembryonic antigen (CEA) and CA19-9 [144]. Another example is given by miR-200, whose increasing serum levels are significantly associated with CRC progression and liver metastasis [145]. However, a recent analysis presented by Hibner et al. [146] underline the usefulness of miRNAs as potential biomarkers for CRC diagnosis and prognosis. 
Additionally, several observational studies about miRNA assessment in CRC clinical trials have been reported. One of these trials, with NCT02635087 code in the ClinicalTrials.gov Identifier, aimed to investigate whether a panel of six miRNAs (miR-21, miR-20a-5p, miR-10a-3p, miR-106b-5p, miR-143-5p and miR-215) could represent a reliable tool to predict the prognosis of the patients with stage II CRC treated with chemotherapy. The miRNAs expression will be evaluated from about 630 surgical tissue samples, and the final results are estimated to be published in July 2020. Another trial, coded NCT03362684 in ClinicalTrials.gov identifier, aimed to establish if the expression of the miR-31-3p and miR-31-5p could be used as prognostic factors for patient outcomes or predict the benefit from anti-EGFR therapy in stage III Colon Cancer. Although this study ended in June 2016, there are no published results yet. New data about the clinical role of miRNA in CRC could come from the trial NCT03309722 initiated in October 2008 by the University of Southampton from UK that aimed to investigate the role of several miRNAs and their targets in colorectal cancer. This observational study does not mention which are the specific miRNAs studied and no results are published yet. The primary outcome measures will include overall survival, disease-free survival, local recurrence and distant recurrence, all evaluated at five years. Estimated enrollment for this study is expected to be around 1000 participants and first results are waited to be published in October 2020.

\section{Conclusions}

Growing evidence consistently shows that miRNAs represent important molecules in the modulation of all hallmarks of cancer. Accordingly, specific miRNAs have been associated with the diagnosis, development, and progression of CRC as well as its liver metastasis. Moreover, changes in the circulating miRNAs levels in patients with solid cancers could be considered for developing novel diagnostic and prognostic factors. In this regard, blood miRNAs transported by CRC-delivered exosomes (miRNA-TEX) have become valuable tools that could be used to predict CRC metastasis in the liver. Several CRC oncomiRs, including miR-18a, mir-328, miR-17-5p and miR-92a, delivered into tumor exosomes, are associated with CRC metastasis, but have also been associated with liver carcinogenesis. However, before their implementing in the clinic as reliable biomarkers, more validation studies are necessary, while standardized methods related to miRNAs processing, expression, and normalization have to be established.

As future challenges, we consider that it would be of interest to evaluate how much of the liver miRNAs could be altered by the chemotherapy regimens used to treat the primary CRC. In the case that these alterations exist, the question arises if and how these miRNAs could be involved in facilitating CRC metastasis in the liver.

Acknowledgments: This research was funded by the grant Partnership for the transfer of knowledge in biogenomics applications in oncology and related fields-BIOGENONCO, Project co-financed by FEDR through Competitiveness Operational Programme 2014-2020, contract no. 10/01.09.2016 and DS was funded by a Ph.D research grant from "Iuliu Hatieganu" University of Medicine and Pharmacy Cluj-Napoca, Romania in accordance to contract No. 7690/105/15.04.2016.

Conflicts of Interest: The authors declare no conflict of interest.

\section{References}

1. Society, A.C. Global Cancer Facts E Figures, 3rd ed.; American Cancer Society: Atlanta, GA, USA, 2015.

2. Scholefield, J.H.; Steele, R.J.; British Society for Gastroenterology; Association of Coloproctology for Great Britain and Ireland. Guidelines for follow up after resection of colorectal cancer. Gut 2002, 51 (Suppl. 5), V3-V5. [CrossRef] [PubMed]

3. Van Cutsem, E.; Cervantes, A.; Adam, R.; Sobrero, A.; Van Krieken, J.H.; Aderka, D.; Aranda Aguilar, E.; Bardelli, A.; Benson, A.; Bodoky, G.; et al. ESMO consensus guidelines for the management of patients with metastatic colorectal cancer. Ann. Oncol. 2016, 27, 1386-1422. [CrossRef] [PubMed] 
4. $\quad$ Benson, A.B., 3rd; Venook, A.P.; Cederquist, L.; Chan, E.; Chen, Y.J.; Cooper, H.S.; Deming, D.; Engstrom, P.F.; Enzinger, P.C.; Fichera, A.; et al. Colon Cancer, Version 1.2017, NCCN Clinical Practice Guidelines in Oncology. J. Natl. Compr. Cancer Netw. 2017, 15, 370-398. [CrossRef]

5. Mitchell, P.S.; Parkin, R.K.; Kroh, E.M.; Fritz, B.R.; Wyman, S.K.; Pogosova-Agadjanyan, E.L.; Peterson, A.; Noteboom, J.; O'Briant, K.C.; Allen, A.; et al. Circulating microRNAs as stable blood-based markers for cancer detection. Proc. Natl. Acad. Sci. USA 2008, 105, 10513-10518. [CrossRef] [PubMed]

6. Hanahan, D.; Weinberg, R.A. The hallmarks of cancer. Cell 2000, 100, 57-70. [CrossRef]

7. Hanahan, D.; Weinberg, R.A. Hallmarks of cancer: The next generation. Cell 2011, 144, 646-674. [CrossRef] [PubMed]

8. Hanahan, D.; Coussens, L.M. Accessories to the crime: Functions of cells recruited to the tumor microenvironment. Cancer Cell 2012, 21, 309-322. [CrossRef] [PubMed]

9. Klampfer, L. Cytokines, inflammation and colon cancer. Curr. Cancer Drug Targets 2011, 11, 451-464. [CrossRef] [PubMed]

10. Tabuso, M.; Homer-Vanniasinkam, S.; Adya, R.; Arasaradnam, R.P. Role of tissue microenvironment resident adipocytes in colon cancer. World J. Gastroenterol. 2017, 23, 5829-5835. [CrossRef] [PubMed]

11. Leslie, A.; Carey, F.A.; Pratt, N.R.; Steele, R.J. The colorectal adenoma-carcinoma sequence. Br. J. Surg. 2002, 89, 845-860. [CrossRef] [PubMed]

12. Bar, M.; Wyman, S.K.; Fritz, B.R.; Qi, J.; Garg, K.S.; Parkin, R.K.; Kroh, E.M.; Bendoraite, A.; Mitchell, P.S.; Nelson, A.M.; et al. MicroRNA discovery and profiling in human embryonic stem cells by deep sequencing of small RNA libraries. Stem Cells 2008, 26, 2496-2505. [CrossRef] [PubMed]

13. Bhalla, A.; Zulfiqar, M.; Bluth, M.H. Molecular Diagnostics in Colorectal Carcinoma: Advances and Applications for 2018. Clin. Lab. Med. 2018, 38, 311-342. [CrossRef] [PubMed]

14. Ma, H.; Brosens, L.A.A.; Offerhaus, G.J.A.; Giardiello, F.M.; de Leng, W.W.J.; Montgomery, E.A. Pathology and genetics of hereditary colorectal cancer. Pathology 2018, 50, 49-59. [CrossRef] [PubMed]

15. Tse, J.W.T.; Jenkins, L.J.; Chionh, F.; Mariadason, J.M. Aberrant DNA Methylation in Colorectal Cancer: What Should We Target? Trends Cancer 2017, 3, 698-712. [CrossRef] [PubMed]

16. Shirafkan, N.; Mansoori, B.; Mohammadi, A.; Shomali, N.; Ghasbi, M.; Baradaran, B. MicroRNAs as novel biomarkers for colorectal cancer: New outlooks. Biomed. Pharmacother. 2018, 97, 1319-1330. [CrossRef] [PubMed]

17. Rupaimoole, R.; Calin, G.A.; Lopez-Berestein, G.; Sood, A.K. miRNA Deregulation in Cancer Cells and the Tumor Microenvironment. Cancer Discov. 2016, 6, 235-246. [CrossRef] [PubMed]

18. Lewis, B.P.; Burge, C.B.; Bartel, D.P. Conserved seed pairing, often flanked by adenosines, indicates that thousands of human genes are microRNA targets. Cell 2005, 120, 15-20. [CrossRef] [PubMed]

19. Krek, A.; Grun, D.; Poy, M.N.; Wolf, R.; Rosenberg, L.; Epstein, E.J.; MacMenamin, P.; da Piedade, I.; Gunsalus, K.C.; Stoffel, M.; et al. Combinatorial microRNA target predictions. Nat. Genet. 2005, 37, 495-500. [CrossRef] [PubMed]

20. Treiber, T.; Treiber, N.; Meister, G. Regulation of microRNA biogenesis and its crosstalk with other cellular pathways. Nat. Rev. Mol. Cell Biol. 2018. [CrossRef] [PubMed]

21. Calin, G.A.; Dumitru, C.D.; Shimizu, M.; Bichi, R.; Zupo, S.; Noch, E.; Aldler, H.; Rattan, S.; Keating, M.; Rai, K.; et al. Frequent deletions and down-regulation of micro-RNA genes miR15 and miR16 at 13q14 in chronic lymphocytic leukemia. Proc. Natl. Acad. Sci. USA 2002, 99, 15524-15529. [CrossRef] [PubMed]

22. Calin, G.A.; Liu, C.G.; Sevignani, C.; Ferracin, M.; Felli, N.; Dumitru, C.D.; Shimizu, M.; Cimmino, A.; Zupo, S.; Dono, M.; et al. MicroRNA profiling reveals distinct signatures in B cell chronic lymphocytic leukemias. Proc. Natl. Acad. Sci. USA 2004, 101, 11755-11760. [CrossRef] [PubMed]

23. Riffo-Campos, A.L.; Riquelme, I.; Brebi-Mieville, P. Tools for Sequence-Based miRNA Target Prediction: What to Choose? Int. J. Mol. Sci. 2016, 17, 1987. [CrossRef] [PubMed]

24. Zhang, B.; Pan, X.; Cobb, G.P.; Anderson, T.A. microRNAs as oncogenes and tumor suppressors. Dev. Biol. 2007, 302, 1-12. [CrossRef] [PubMed]

25. Michael, M.Z.; SM, O.C.; van Holst Pellekaan, N.G.; Young, G.P.; James, R.J. Reduced accumulation of specific microRNAs in colorectal neoplasia. Mol. Cancer Res. 2003, 1, 882-891. [PubMed]

26. Oberg, A.L.; French, A.J.; Sarver, A.L.; Subramanian, S.; Morlan, B.W.; Riska, S.M.; Borralho, P.M.; Cunningham, J.M.; Boardman, L.A.; Wang, L.; et al. miRNA expression in colon polyps provides evidence for a multihit model of colon cancer. PLoS ONE 2011, 6, e20465. [CrossRef] [PubMed] 
27. Bartley, A.N.; Yao, H.; Barkoh, B.A.; Ivan, C.; Mishra, B.M.; Rashid, A.; Calin, G.A.; Luthra, R.; Hamilton, S.R. Complex patterns of altered MicroRNA expression during the adenoma-adenocarcinoma sequence for microsatellite-stable colorectal cancer. Clin. Cancer Res. 2011, 17, 7283-7293. [CrossRef] [PubMed]

28. Mohammadi, A.; Mansoori, B.; Baradaran, B. The role of microRNAs in colorectal cancer. Biomed. Pharmacother. 2016, 84, 705-713. [CrossRef] [PubMed]

29. Rahmani, F.; Avan, A.; Hashemy, S.I.; Hassanian, S.M. Role of Wnt/beta-catenin signaling regulatory microRNAs in the pathogenesis of colorectal cancer. J. Cell Physiol. 2018, 233, 811-817. [CrossRef] [PubMed]

30. Falzone, L.; Scola, L.; Zanghi, A.; Biondi, A.; Di Cataldo, A.; Libra, M.; Candido, S. Integrated analysis of colorectal cancer microRNA datasets: Identification of microRNAs associated with tumor development. Aging (Albany N. Y.) 2018, 10, 1000-1014. [CrossRef] [PubMed]

31. Fu, J.; Tang, W.; Du, P.; Wang, G.; Chen, W.; Li, J.; Zhu, Y.; Gao, J.; Cui, L. Identifying microRNA-mRNA regulatory network in colorectal cancer by a combination of expression profile and bioinformatics analysis. BMC Syst. Biol. 2012, 6, 68. [CrossRef] [PubMed]

32. Nagel, R.; le Sage, C.; Diosdado, B.; van der Waal, M.; Oude Vrielink, J.A.; Bolijn, A.; Meijer, G.A.; Agami, R. Regulation of the adenomatous polyposis coli gene by the miR-135 family in colorectal cancer. Cancer Res. 2008, 68, 5795-5802. [CrossRef] [PubMed]

33. Zhang, Y.; Guo, L.; Li, Y.; Feng, G.H.; Teng, F.; Li, W.; Zhou, Q. MicroRNA-494 promotes cancer progression and targets adenomatous polyposis coli in colorectal cancer. Mol. Cancer 2018, 17, 1. [CrossRef] [PubMed]

34. Liu, N.; Jiang, F.; Han, X.Y.; Li, M.; Chen, W.J.; Liu, Q.C.; Liao, C.X.; Lv, Y.F. MiRNA-155 promotes the invasion of colorectal cancer SW-480 cells through regulating the Wnt/beta-catenin. Eur. Rev. Med. Pharmacol. Sci. 2018, 22, 101-109. [PubMed]

35. Hwang, W.L.; Yang, M.H. Numb is involved in the non-random segregation of subcellular vesicles in colorectal cancer stem cells. Cell Cycle 2016, 15, 2697-2703. [CrossRef] [PubMed]

36. Cao, J.; Yan, X.R.; Liu, T.; Han, X.B.; Yu, J.J.; Liu, S.H.; Wang, L.B. MicroRNA-552 promotes tumor cell proliferation and migration by directly targeting DACH1 via the Wnt/beta-catenin signaling pathway in colorectal cancer. Oncol. Lett. 2017, 14, 3795-3802. [CrossRef] [PubMed]

37. Li, Y.; Lauriola, M.; Kim, D.; Francesconi, M.; D’Uva, G.; Shibata, D.; Malafa, M.P.; Yeatman, T.J.; Coppola, D.; Solmi, R.; et al. Adenomatous polyposis coli (APC) regulates miR17-92 cluster through beta-catenin pathway in colorectal cancer. Oncogene 2016, 35, 4558-4568. [CrossRef] [PubMed]

38. Liu, Y.; Liu, R.; Yang, F.; Cheng, R.; Chen, X.; Cui, S.; Gu, Y.; Sun, W.; You, C.; Liu, Z.; et al. miR-19a promotes colorectal cancer proliferation and migration by targeting TIA1. Mol. Cancer 2017, 16, 53. [CrossRef] [PubMed]

39. Li, T.; Lai, Q.; Wang, S.; Cai, J.; Xiao, Z.; Deng, D.; He, L.; Jiao, H.; Ye, Y.; Liang, L.; et al. MicroRNA-224 sustains Wnt/beta-catenin signaling and promotes aggressive phenotype of colorectal cancer. J. Exp. Clin. Cancer Res. 2016, 35, 21. [CrossRef] [PubMed]

40. Fasihi, A.; M Soltani, B.; Atashi, A.; Nasiri, S. Introduction of hsa-miR-103a and hsa-miR-1827 and hsa-miR-137 as new regulators of Wnt signaling pathway and their relation to colorectal carcinoma. J. Cell. Biochem. 2018, 119, 5104-5117. [CrossRef] [PubMed]

41. Ji, S.; Ye, G.; Zhang, J.; Wang, L.; Wang, T.; Wang, Z.; Zhang, T.; Wang, G.; Guo, Z.; Luo, Y.; et al. miR-574-5p negatively regulates Qki6/7 to impact beta-catenin/Wnt signalling and the development of colorectal cancer. Gut 2013, 62, 716-726. [CrossRef] [PubMed]

42. Phesse, T.; Flanagan, D.; Vincan, E. Frizzled7: A Promising Achilles' Heel for Targeting the Wnt Receptor Complex to Treat Cancer. Cancers (Basel) 2016, 8, 50. [CrossRef] [PubMed]

43. Zhang, N.; Li, X.; Wu, C.W.; Dong, Y.; Cai, M.; Mok, M.T.; Wang, H.; Chen, J.; Ng, S.S.; Chen, M.; et al. microRNA-7 is a novel inhibitor of YY1 contributing to colorectal tumorigenesis. Oncogene 2013, 32, 5078-5088. [CrossRef] [PubMed]

44. Tang, Q.; Zou, Z.; Zou, C.; Zhang, Q.; Huang, R.; Guan, X.; Li, Q.; Han, Z.; Wang, D.; Wei, H.; et al. MicroRNA-93 suppress colorectal cancer development via Wnt/beta-catenin pathway downregulating. Tumour Biol. 2015, 36, 1701-1710. [CrossRef] [PubMed]

45. Dong-Xu, W.; Jia, L.; Su-Juan, Z. MicroRNA-185 is a novel tumor suppressor by negatively modulating the Wnt/beta-catenin pathway in human colorectal cancer. Indian J. Cancer 2015, 52 (Suppl. 3), E182-E185. [CrossRef] [PubMed] 
46. Zhu, J.; Chen, L.; Zou, L.; Yang, P.; Wu, R.; Mao, Y.; Zhou, H.; Li, R.; Wang, K.; Wang, W.; et al. MiR-20b, -21 , and $-130 \mathrm{~b}$ inhibit PTEN expression resulting in B7-H1 over-expression in advanced colorectal cancer. Hum. Immunol. 2014, 75, 348-353. [CrossRef] [PubMed]

47. Fan, D.; Lin, X.; Zhang, F.; Zhong, W.; Hu, J.; Chen, Y.; Cai, Z.; Zou, Y.; He, X.; Chen, X.; et al. MicroRNA $26 \mathrm{~b}$ promotes colorectal cancer metastasis by downregulating phosphatase and tensin homolog and wingless-type MMTV integration site family member 5A. Cancer Sci. 2018, 109, 354-362. [CrossRef] [PubMed]

48. Jia, L.; Luo, S.; Ren, X.; Li, Y.; Hu, J.; Liu, B.; Zhao, L.; Shan, Y.; Zhou, H. miR-182 and miR-135b Mediate the Tumorigenesis and Invasiveness of Colorectal Cancer Cells via Targeting ST6GALNAC2 and PI3K/AKT Pathway. Dig. Dis. Sci. 2017, 62, 3447-3459. [CrossRef] [PubMed]

49. Pagliuca, A.; Valvo, C.; Fabrizi, E.; di Martino, S.; Biffoni, M.; Runci, D.; Forte, S.; De Maria, R.; Ricci-Vitiani, L. Analysis of the combined action of miR-143 and miR-145 on oncogenic pathways in colorectal cancer cells reveals a coordinate program of gene repression. Oncogene 2013, 32, 4806-4813. [CrossRef] [PubMed]

50. Pan, X.M.; Sun, R.F.; Li, Z.H.; Guo, X.M.; Zhang, Z.; Qin, H.J.; Xu, G.H.; Gao, L.B. A let-7 KRAS rs712 polymorphism increases colorectal cancer risk. Tumour Biol. 2014, 35, 831-835. [CrossRef] [PubMed]

51. Chen, M.; Lin, M.; Wang, X. Overexpression of miR-19a inhibits colorectal cancer angiogenesis by suppressing KRAS expression. Oncol. Rep. 2018, 39, 619-626. [CrossRef] [PubMed]

52. Huang, L.; Wen, C.; Yang, X.; Lou, Q.; Wang, X.; Che, J.; Chen, J.; Yang, Z.; Wu, X.; Huang, M.; et al. PEAK1, acting as a tumor promoter in colorectal cancer, is regulated by the EGFR/KRas signaling axis and miR-181d. Cell Death Dis. 2018, 9, 271. [CrossRef] [PubMed]

53. Shen, H.; Xing, C.; Cui, K.; Li, Y.; Zhang, J.; Du, R.; Zhang, X.; Li, Y. MicroRNA-30a attenuates mutant KRAS-driven colorectal tumorigenesis via direct suppression of ME1. Cell Death Differ. 2017, 24, 1253-1262. [CrossRef] [PubMed]

54. Zhang, N.; Lu, C.; Chen, L. miR-217 regulates tumor growth and apoptosis by targeting the MAPK signaling pathway in colorectal cancer. Oncol. Lett. 2016, 12, 4589-4597. [CrossRef] [PubMed]

55. Hata, T.; Mokutani, Y.; Takahashi, H.; Inoue, A.; Munakata, K.; Nagata, K.; Haraguchi, N.; Nishimura, J.; Hata, T.; Matsuda, C.; et al. Identification of microRNA-487b as a negative regulator of liver metastasis by regulation of KRAS in colorectal cancer. Int. J. Oncol. 2017, 50, 487-496. [CrossRef] [PubMed]

56. You, C.; Liang, H.; Sun, W.; Li, J.; Liu, Y.; Fan, Q.; Zhang, H.; Yue, X.; Li, J.; Chen, X.; et al. Deregulation of the miR-16-KRAS axis promotes colorectal cancer. Sci. Rep. 2016, 6, 37459. [CrossRef] [PubMed]

57. Wang, Y.X.; Chen, Y.R.; Liu, S.S.; Ye, Y.P.; Jiao, H.L.; Wang, S.Y.; Xiao, Z.Y.; Wei, W.T.; Qiu, J.F.; Liang, L.; et al. MiR-384 inhibits human colorectal cancer metastasis by targeting KRAS and CDC42. Oncotarget 2016, 7, 84826-84838. [CrossRef] [PubMed]

58. Liang, L.; Gao, C.; Li, Y.; Sun, M.; Xu, J.; Li, H.; Jia, L.; Zhao, Y. miR-125a-3p/FUT5-FUT6 axis mediates colorectal cancer cell proliferation, migration, invasion and pathological angiogenesis via PI3K-Akt pathway. Cell Death Dis. 2017, 8, e2968. [CrossRef] [PubMed]

59. Li, J.; Liang, H.; Bai, M.; Ning, T.; Wang, C.; Fan, Q.; Wang, Y.; Fu, Z.; Wang, N.; Liu, R.; et al. miR-135b Promotes Cancer Progression by Targeting Transforming Growth Factor Beta Receptor II (TGFBR2) in Colorectal Cancer. PLoS ONE 2015, 10, e0130194. [CrossRef] [PubMed]

60. Zhang, W.; Zhang, T.; Jin, R.; Zhao, H.; Hu, J.; Feng, B.; Zang, L.; Zheng, M.; Wang, M. MicroRNA-301a promotes migration and invasion by targeting TGFBR2 in human colorectal cancer. J. Exp. Clin. Cancer Res. 2014, 33, 113. [CrossRef] [PubMed]

61. Cheng, D.; Zhao, S.; Tang, H.; Zhang, D.; Sun, H.; Yu, F.; Jiang, W.; Yue, B.; Wang, J.; Zhang, M.; et al. MicroRNA-20a-5p promotes colorectal cancer invasion and metastasis by downregulating Smad4. Oncotarget 2016, 7, 45199-45213. [CrossRef] [PubMed]

62. Ling, H.; Pickard, K.; Ivan, C.; Isella, C.; Ikuo, M.; Mitter, R.; Spizzo, R.; Bullock, M.; Braicu, C.; Pileczki, V.; et al. The clinical and biological significance of MIR-224 expression in colorectal cancer metastasis. Gut 2016, 65, 977-989. [CrossRef] [PubMed]

63. Nishida, N.; Yokobori, T.; Mimori, K.; Sudo, T.; Tanaka, F.; Shibata, K.; Ishii, H.; Doki, Y.; Kuwano, H.; Mori, M. MicroRNA miR-125b is a prognostic marker in human colorectal cancer. Int. J. Oncol. 2011, 38, 1437-1443. [PubMed]

64. Hu, W.; Chan, C.S.; Wu, R.; Zhang, C.; Sun, Y.; Song, J.S.; Tang, L.H.; Levine, A.J.; Feng, Z. Negative regulation of tumor suppressor p53 by microRNA miR-504. Mol. Cell 2010, 38, 689-699. [CrossRef] [PubMed] 
65. Kumar, M.; Lu, Z.; Takwi, A.A.; Chen, W.; Callander, N.S.; Ramos, K.S.; Young, K.H.; Li, Y. Negative regulation of the tumor suppressor p53 gene by microRNAs. Oncogene 2011, 30, 843-853. [CrossRef] [PubMed]

66. Mori, F.; Ferraiuolo, M.; Santoro, R.; Sacconi, A.; Goeman, F.; Pallocca, M.; Pulito, C.; Korita, E.; Fanciulli, M.; Muti, P.; et al. Multitargeting activity of miR-24 inhibits long-term melatonin anticancer effects. Oncotarget 2016, 7, 20532-20548. [CrossRef] [PubMed]

67. Tay, Y.; Tan, S.M.; Karreth, F.A.; Lieberman, J.; Pandolfi, P.P. Characterization of dual PTEN and p53-targeting microRNAs identifies microRNA-638/Dnm2 as a two-hit oncogenic locus. Cell Rep. 2014, 8, 714-722. [CrossRef] [PubMed]

68. Ma, K.; Pan, X.; Fan, P.; He, Y.; Gu, J.; Wang, W.; Zhang, T.; Li, Z.; Luo, X. Loss of miR-638 in vitro promotes cell invasion and a mesenchymal-like transition by influencing SOX2 expression in colorectal carcinoma cells. Mol. Cancer 2014, 13, 118. [CrossRef] [PubMed]

69. Zhang, J.; Fei, B.; Wang, Q.; Song, M.; Yin, Y.; Zhang, B.; Ni, S.; Guo, W.; Bian, Z.; Quan, C.; et al. MicroRNA-638 inhibits cell proliferation, invasion and regulates cell cycle by targeting tetraspanin 1 in human colorectal carcinoma. Oncotarget 2014, 5, 12083-12096. [CrossRef] [PubMed]

70. Yamakuchi, M.; Ferlito, M.; Lowenstein, C.J. miR-34a repression of SIRT1 regulates apoptosis. Proc. Natl. Acad. Sci. USA 2008, 105, 13421-13426. [CrossRef] [PubMed]

71. Wee, P.; Wang, Z. Epidermal Growth Factor Receptor Cell Proliferation Signaling Pathways. Cancers (Basel) 2017, 9, 52. [CrossRef]

72. Akao, Y.; Nakagawa, Y.; Naoe, T. let-7 microRNA functions as a potential growth suppressor in human colon cancer cells. Biol. Pharm. Bull. 2006, 29, 903-906. [CrossRef] [PubMed]

73. Ota, T.; Doi, K.; Fujimoto, T.; Tanaka, Y.; Ogawa, M.; Matsuzaki, H.; Kuroki, M.; Miyamoto, S.; Shirasawa, S.; Tsunoda, T. KRAS up-regulates the expression of miR-181a, miR-200c and miR-210 in a three-dimensional-specific manner in DLD-1 colorectal cancer cells. Anticancer Res. 2012, 32, 2271-2275. [PubMed]

74. Roh, M.S.; Lee, H.W.; Jung, S.B.; Kim, K.; Lee, E.H.; Park, M.I.; Lee, J.S.; Kim, M.S. Expression of miR-200c and its clinicopathological significance in patients with colorectal cancer. Pathol. Res. Pract. 2018, 214, 350-355. [CrossRef] [PubMed]

75. Velho, S.; Oliveira, C.; Ferreira, A.; Ferreira, A.C.; Suriano, G.; Schwartz, S., Jr.; Duval, A.; Carneiro, F.; Machado, J.C.; Hamelin, R.; et al. The prevalence of PIK3CA mutations in gastric and colon cancer. Eur. J. Cancer 2005, 41, 1649-1654. [CrossRef] [PubMed]

76. Danielsen, S.A.; Eide, P.W.; Nesbakken, A.; Guren, T.; Leithe, E.; Lothe, R.A. Portrait of the PI3K/AKT pathway in colorectal cancer. Biochim. Biophys. Acta 2015, 1855, 104-121. [CrossRef] [PubMed]

77. Principe, D.R.; Doll, J.A.; Bauer, J.; Jung, B.; Munshi, H.G.; Bartholin, L.; Pasche, B.; Lee, C.; Grippo, P.J. TGF-beta: Duality of function between tumor prevention and carcinogenesis. J. Natl. Cancer Inst. 2014, 106, djt369. [CrossRef] [PubMed]

78. Ozaki, T.; Nakagawara, A. Role of p53 in Cell Death and Human Cancers. Cancers (Basel) 2011, 3, 994-1013. [CrossRef] [PubMed]

79. Kandoth, C.; McLellan, M.D.; Vandin, F.; Ye, K.; Niu, B.; Lu, C.; Xie, M.; Zhang, Q.; McMichael, J.F.; Wyczalkowski, M.A.; et al. Mutational landscape and significance across 12 major cancer types. Nature 2013, 502, 333-339. [CrossRef] [PubMed]

80. Goeman, F.; Strano, S.; Blandino, G. MicroRNAs as Key Effectors in the p53 Network. Int. Rev. Cell Mol. Biol. 2017, 333, 51-90. [PubMed]

81. Thiery, J.P.; Acloque, H.; Huang, R.Y.; Nieto, M.A. Epithelial-mesenchymal transitions in development and disease. Cell 2009, 139, 871-890. [CrossRef] [PubMed]

82. Vu, T.; Datta, P.K. Regulation of EMT in Colorectal Cancer: A Culprit in Metastasis. Cancers (Basel) 2017, 9, 171. [CrossRef] [PubMed]

83. Costa, V.; Lo Dico, A.; Rizzo, A.; Rajata, F.; Tripodi, M.; Alessandro, R.; Conigliaro, A. MiR-675-5p supports hypoxia induced epithelial to mesenchymal transition in colon cancer cells. Oncotarget 2017, 8, 24292-24302. [CrossRef] [PubMed]

84. Siemens, H.; Jackstadt, R.; Hunten, S.; Kaller, M.; Menssen, A.; Gotz, U.; Hermeking, H. miR-34 and SNAIL form a double-negative feedback loop to regulate epithelial-mesenchymal transitions. Cell Cycle 2011, 10, 4256-4271. [CrossRef] [PubMed] 
85. Hahn, S.; Jackstadt, R.; Siemens, H.; Hunten, S.; Hermeking, H. SNAIL and miR-34a feed-forward regulation of ZNF281/ZBP99 promotes epithelial-mesenchymal transition. EMBO J. 2013, 32, 3079-3095. [CrossRef] [PubMed]

86. Cui, F.; Wang, S.; Lao, I.; Zhou, C.; Kong, H.; Bayaxi, N.; Li, J.; Chen, Q.; Zhu, T.; Zhu, H. miR-375 inhibits the invasion and metastasis of colorectal cancer via targeting SP1 and regulating EMT-associated genes. Oncol. Rep. 2016, 36, 487-493. [CrossRef] [PubMed]

87. Chen, Y.; Jiang, J.; Zhao, M.; Luo, X.; Liang, Z.; Zhen, Y.; Fu, Q.; Deng, X.; Lin, X.; Li, L.; et al. microRNA-374a suppresses colon cancer progression by directly reducing CCND1 to inactivate the PI3K/AKT pathway. Oncotarget 2016, 7, 41306-41319. [CrossRef] [PubMed]

88. Hur, K.; Toiyama, Y.; Takahashi, M.; Balaguer, F.; Nagasaka, T.; Koike, J.; Hemmi, H.; Koi, M.; Boland, C.R.; Goel, A. MicroRNA-200c modulates epithelial-to-mesenchymal transition (EMT) in human colorectal cancer metastasis. Gut 2013, 62, 1315-1326. [CrossRef] [PubMed]

89. Tian, Y.; Pan, Q.; Shang, Y.; Zhu, R.; Ye, J.; Liu, Y.; Zhong, X.; Li, S.; He, Y.; Chen, L.; et al. MicroRNA-200 (miR-200) cluster regulation by achaete scute-like 2 (Ascl2): Impact on the epithelial-mesenchymal transition in colon cancer cells. J. Biol. Chem. 2014, 289, 36101-36115. [CrossRef] [PubMed]

90. Sun, Y.; Shen, S.; Liu, X.; Tang, H.; Wang, Z.; Yu, Z.; Li, X.; Wu, M. MiR-429 inhibits cells growth and invasion and regulates EMT-related marker genes by targeting Onecut2 in colorectal carcinoma. Mol. Cell. Biochem. 2014, 390, 19-30. [CrossRef] [PubMed]

91. Sun, Z.; Zhang, Z.; Liu, Z.; Qiu, B.; Liu, K.; Dong, G. MicroRNA-335 inhibits invasion and metastasis of colorectal cancer by targeting ZEB2. Med. Oncol. 2014, 31, 982. [CrossRef] [PubMed]

92. Zheng, Y.B.; Luo, H.P.; Shi, Q.; Hao, Z.N.; Ding, Y.; Wang, Q.S.; Li, S.B.; Xiao, G.C.; Tong, S.L. miR-132 inhibits colorectal cancer invasion and metastasis via directly targeting ZEB2. World J. Gastroenterol. 2014, 20, 6515-6522. [CrossRef] [PubMed]

93. Geng, L.; Chaudhuri, A.; Talmon, G.; Wisecarver, J.L.; Are, C.; Brattain, M.; Wang, J. MicroRNA-192 suppresses liver metastasis of colon cancer. Oncogene 2014, 33, 5332-5340. [CrossRef] [PubMed]

94. Zhang, G.J.; Li, Y.; Zhou, H.; Xiao, H.X.; Zhou, T. miR20a is an independent prognostic factor in colorectal cancer and is involved in cell metastasis. Mol. Med. Rep. 2014, 10, 283-291. [CrossRef] [PubMed]

95. Xu, T.; Jing, C.; Shi, Y.; Miao, R.; Peng, L.; Kong, S.; Ma, Y.; Li, L. microRNA-20a enhances the epithelial-to-mesenchymal transition of colorectal cancer cells by modulating matrix metalloproteinases. Exp. Ther. Med. 2015, 10, 683-688. [CrossRef] [PubMed]

96. Zhao, S.; Sun, H.; Jiang, W.; Mi, Y.; Zhang, D.; Wen, Y.; Cheng, D.; Tang, H.; Wu, S.; Yu, Y.; et al. miR-4775 promotes colorectal cancer invasion and metastasis via the Smad7/TGFbeta-mediated epithelial to mesenchymal transition. Mol. Cancer 2017, 16, 12. [CrossRef] [PubMed]

97. Bu, P.; Wang, L.; Chen, K.Y.; Rakhilin, N.; Sun, J.; Closa, A.; Tung, K.L.; King, S.; Kristine Varanko, A.; $\mathrm{Xu}$, Y.; et al. miR-1269 promotes metastasis and forms a positive feedback loop with TGF-beta. Nat. Commun. 2015, 6, 6879. [CrossRef] [PubMed]

98. Wang, H.; Nie, L.; Wu, L.; Liu, Q.; Guo, X. NR2F2 inhibits Smad7 expression and promotes TGF-beta-dependent epithelial-mesenchymal transition of CRC via transactivation of miR-21. Biochem. Biophys. Res. Commun. 2017, 485, 181-188. [CrossRef] [PubMed]

99. Guo, Y.H.; Wang, L.Q.; Li, B.; Xu, H.; Yang, J.H.; Zheng, L.S.; Yu, P.; Zhou, A.D.; Zhang, Y.; Xie, S.J.; et al. Wnt/beta-catenin pathway transactivates microRNA-150 that promotes EMT of colorectal cancer cells by suppressing CREB signaling. Oncotarget 2016, 7, 42513-42526. [CrossRef] [PubMed]

100. Cai, H.K.; Chen, X.; Tang, Y.H.; Deng, Y.C. MicroRNA-194 modulates epithelial-mesenchymal transition in human colorectal cancer metastasis. Onco Targets Ther. 2017, 10, 1269-1278. [CrossRef] [PubMed]

101. Vishnubalaji, R.; Hamam, R.; Yue, S.; Al-Obeed, O.; Kassem, M.; Liu, F.F.; Aldahmash, A.; Alajez, N.M. MicroRNA-320 suppresses colorectal cancer by targeting SOX4, FOXM1, and FOXQ1. Oncotarget 2016, 7, 35789-35802. [CrossRef] [PubMed]

102. Zhang, F.; Luo, Y.; Shao, Z.; Xu, L.; Liu, X.; Niu, Y.; Shi, J.; Sun, X.; Liu, Y.; Ding, Y.; et al. MicroRNA-187, a downstream effector of TGFbeta pathway, suppresses Smad-mediated epithelial-mesenchymal transition in colorectal cancer. Cancer Lett. 2016, 373, 203-213. [CrossRef] [PubMed]

103. Kim, N.H.; Kim, H.S.; Kim, N.G.; Lee, I.; Choi, H.S.; Li, X.Y.; Kang, S.E.; Cha, S.Y.; Ryu, J.K.; Na, J.M.; et al. p53 and microRNA-34 are suppressors of canonical Wnt signaling. Sci. Signal. 2011, 4, ra71. [CrossRef] [PubMed] 
104. Siemens, H.; Neumann, J.; Jackstadt, R.; Mansmann, U.; Horst, D.; Kirchner, T.; Hermeking, H. Detection of miR-34a promoter methylation in combination with elevated expression of c-Met and beta-catenin predicts distant metastasis of colon cancer. Clin. Cancer Res. 2013, 19, 710-720. [CrossRef] [PubMed]

105. Sathyanarayanan, A.; Chandrasekaran, K.S.; Karunagaran, D. microRNA-145 downregulates SIP1-expression but differentially regulates proliferation, migration, invasion and Wnt signaling in SW480 and SW620 cells. J. Cell. Biochem. 2018, 119, 2022-2035. [CrossRef] [PubMed]

106. Subramanian, M.; Rao, S.R.; Thacker, P.; Chatterjee, S.; Karunagaran, D. MiR-29b downregulates canonical Wnt signaling by suppressing coactivators of beta-catenin in human colorectal cancer cells. J. Cell. Biochem. 2014, 115, 1974-1984. [PubMed]

107. Ding, D.; Li, C.; Zhao, T.; Li, D.; Yang, L.; Zhang, B. LncRNA H19/miR-29b-3p/PGRN Axis Promoted Epithelial-Mesenchymal Transition of Colorectal Cancer Cells by Acting on Wnt Signaling. Mol. Cells 2018, 41, 423-435. [PubMed]

108. Han, H.B.; Gu, J.; Zuo, H.J.; Chen, Z.G.; Zhao, W.; Li, M.; Ji, D.B.; Lu, Y.Y.; Zhang, Z.Q. Let-7c functions as a metastasis suppressor by targeting MMP11 and PBX3 in colorectal cancer. J. Pathol. 2012, 226, 544-555. [CrossRef] [PubMed]

109. Lu, M.H.; Huang, C.C.; Pan, M.R.; Chen, H.H.; Hung, W.C. Prospero homeobox 1 promotes epithelialmesenchymal transition in colon cancer cells by inhibiting E-cadherin via miR-9. Clin. Cancer Res. 2012, 18, 6416-6425. [CrossRef] [PubMed]

110. Rahbari, N.N.; Bork, U.; Scholch, S.; Reissfelder, C.; Thorlund, K.; Betzler, A.; Kahlert, C.; Schneider, M.; Ulrich, A.B.; Buchler, M.W.; et al. Metastatic Spread Emerging From Liver Metastases of Colorectal Cancer: Does the Seed Leave the Soil Again? Ann. Surg. 2016, 263, 345-352. [CrossRef] [PubMed]

111. Jolly, M.K.; Tripathi, S.C.; Somarelli, J.A.; Hanash, S.M.; Levine, H. Epithelial/mesenchymal plasticity: How have quantitative mathematical models helped improve our understanding? Mol. Oncol. 2017, 11, 739-754. [CrossRef] [PubMed]

112. Squadrito, M.L.; Baer, C.; Burdet, F.; Maderna, C.; Gilfillan, G.D.; Lyle, R.; Ibberson, M.; De Palma, M. Endogenous RNAs modulate microRNA sorting to exosomes and transfer to acceptor cells. Cell Rep. 2014, 8, 1432-1446. [CrossRef] [PubMed]

113. Bebelman, M.P.; Smit, M.J.; Pegtel, D.M.; Baglio, S.R. Biogenesis and function of extracellular vesicles in cancer. Pharmacol. Ther. 2018, 188, 1-11. [CrossRef] [PubMed]

114. Hoshino, A.; Costa-Silva, B.; Shen, T.L.; Rodrigues, G.; Hashimoto, A.; Tesic Mark, M.; Molina, H.; Kohsaka, S.; Di Giannatale, A.; Ceder, S.; et al. Tumour exosome integrins determine organotropic metastasis. Nature 2015, 527, 329-335. [CrossRef] [PubMed]

115. Kim, J.; Mori, T.; Chen, S.L.; Amersi, F.F.; Martinez, S.R.; Kuo, C.; Turner, R.R.; Ye, X.; Bilchik, A.J.; Morton, D.L.; et al. Chemokine receptor CXCR4 expression in patients with melanoma and colorectal cancer liver metastases and the association with disease outcome. Ann. Surg. 2006, 244, 113-120. [CrossRef] [PubMed]

116. Ghadjar, P.; Coupland, S.E.; Na, I.K.; Noutsias, M.; Letsch, A.; Stroux, A.; Bauer, S.; Buhr, H.J.; Thiel, E.; Scheibenbogen, C.; et al. Chemokine receptor CCR6 expression level and liver metastases in colorectal cancer. J. Clin. Oncol. 2006, 24, 1910-1916. [CrossRef] [PubMed]

117. Qiu, M.; Hu, J.; Yang, D.; Cosgrove, D.P.; Xu, R. Pattern of distant metastases in colorectal cancer: A SEER based study. Oncotarget 2015, 6, 38658-38666. [CrossRef] [PubMed]

118. Pegtel, D.M.; Cosmopoulos, K.; Thorley-Lawson, D.A.; van Eijndhoven, M.A.; Hopmans, E.S.; Lindenberg, J.L.; de Gruijl, T.D.; Wurdinger, T.; Middeldorp, J.M. Functional delivery of viral miRNAs via exosomes. Proc. Natl. Acad. Sci. USA 2010, 107, 6328-6333. [CrossRef] [PubMed]

119. Meehan, K.; Vella, L.J. The contribution of tumour-derived exosomes to the hallmarks of cancer. Crit. Rev. Clin. Lab. Sci. 2016, 53, 121-131. [CrossRef] [PubMed]

120. Koppers-Lalic, D.; Hackenberg, M.; Bijnsdorp, I.V.; van Eijndhoven, M.A.J.; Sadek, P.; Sie, D.; Zini, N.; Middeldorp, J.M.; Ylstra, B.; de Menezes, R.X.; et al. Nontemplated nucleotide additions distinguish the small RNA composition in cells from exosomes. Cell Rep. 2014, 8, 1649-1658. [CrossRef] [PubMed]

121. Wang, X.; Ding, X.; Nan, L.; Wang, Y.; Wang, J.; Yan, Z.; Zhang, W.; Sun, J.; Zhu, W.; Ni, B.; et al. Investigation of the roles of exosomes in colorectal cancer liver metastasis. Oncol. Rep. 2015, 33, 2445-2453. [CrossRef] [PubMed] 
122. Takano, Y.; Masuda, T.; Iinuma, H.; Yamaguchi, R.; Sato, K.; Tobo, T.; Hirata, H.; Kuroda, Y.; Nambara, S.; Hayashi, N.; et al. Circulating exosomal microRNA-203 is associated with metastasis possibly via inducing tumor-associated macrophages in colorectal cancer. Oncotarget 2017, 8, 78598-78613. [CrossRef] [PubMed]

123. Shao, Y.; Chen, T.; Zheng, X.; Yang, S.; Xu, K.; Chen, X.; Xu, F.; Wang, L.; Shen, Y.; Wang, T.; et al. Colorectal Cancer-derived Small Extracellular Vesicles Establish an Inflammatory Pre-metastatic Niche in Liver Metastasis. Carcinogenesis 2018. [CrossRef] [PubMed]

124. Yan, S.; Jiang, Y.; Liang, C.; Cheng, M.; Jin, C.; Duan, Q.; Xu, D.; Yang, L.; Zhang, X.; Ren, B.; et al. Exosomal miR-6803-5p as potential diagnostic and prognostic marker in colorectal cancer. J. Cell. Biochem. 2018, 119, 4113-4119. [CrossRef] [PubMed]

125. Peng, Z.Y.; Gu, R.H.; Yan, B. Downregulation of exosome-encapsulated miR-548c-5p is associated with poor prognosis in colorectal cancer. J. Cell. Biochem. 2018. [CrossRef] [PubMed]

126. Yan, S.; Han, B.; Gao, S.; Wang, X.; Wang, Z.; Wang, F.; Zhang, J.; Xu, D.; Sun, B. Exosome-encapsulated microRNAs as circulating biomarkers for colorectal cancer. Oncotarget 2017, 8, 60149-60158. [CrossRef] [PubMed]

127. Fu, F.; Jiang, W.; Zhou, L.; Chen, Z. Circulating Exosomal miR-17-5p and miR-92a-3p Predict Pathologic Stage and Grade of Colorectal Cancer. Transl. Oncol. 2018, 11, 221-232. [CrossRef] [PubMed]

128. Monzo, M.; Santasusagna, S.; Moreno, I.; Martinez, F.; Hernandez, R.; Munoz, C.; Castellano, J.J.; Moreno, J.; Navarro, A. Exosomal microRNAs isolated from plasma of mesenteric veins linked to liver metastases in resected patients with colon cancer. Oncotarget 2017, 8, 30859-30869. [CrossRef] [PubMed]

129. Teng, Y.; Ren, Y.; Hu, X.; Mu, J.; Samykutty, A.; Zhuang, X.; Deng, Z.; Kumar, A.; Zhang, L.; Merchant, M.L.; et al. MVP-mediated exosomal sorting of miR-193a promotes colon cancer progression. Nat. Commun. 2017, 8, 14448. [CrossRef] [PubMed]

130. Melo, S.A.; Sugimoto, H.; O’Connell, J.T.; Kato, N.; Villanueva, A.; Vidal, A.; Qiu, L.; Vitkin, E.; Perelman, L.T.; Melo, C.A.; et al. Cancer exosomes perform cell-independent microRNA biogenesis and promote tumorigenesis. Cancer Cell 2014, 26, 707-721. [CrossRef] [PubMed]

131. Whiteside, T.L. Exosomes and tumor-mediated immune suppression. J. Clin. Investig. 2016, 126, 1216-1223. [CrossRef] [PubMed]

132. Mao, B.; Xiao, H.; Zhang, Z.; Wang, D.; Wang, G. MicroRNA21 regulates the expression of BTG2 in HepG2 liver cancer cells. Mol. Med. Rep. 2015, 12, 4917-4924. [CrossRef] [PubMed]

133. Sanchez-Mejias, A.; Kwon, J.; Chew, X.H.; Siemens, A.; Sohn, H.S.; Jing, G.; Zhang, B.; Yang, H.; Tay, Y. A novel SOCS5/miR-18/miR-25 axis promotes tumorigenesis in liver cancer. Int. J. Cancer 2018. [CrossRef] [PubMed]

134. Yongyu, Z.; Lewei, Y.; Jian, L.; Yuqin, S. MicroRNA-18a targets IRF2 and CBX7 to promote cell proliferation in hepatocellular carcinoma. Oncol. Res. 2018. [CrossRef] [PubMed]

135. Zhang, X.; Yu, B.; Zhang, F.; Guo, Z.; Li, L. microRNA-18a Promotes Cell Migration and Invasion Through Inhibiting Dicer 1 Expression in Hepatocellular Carcinoma In Vitro. Chin. Med. Sci. J. 2017, 32, $34-43$. [CrossRef] [PubMed]

136. Luo, X.; Yang, S.; Zhou, C.; Pan, F.; Li, Q.; Ma, S. MicroRNA-328 enhances cellular motility through posttranscriptional regulation of PTPRJ in human hepatocellular carcinoma. Onco Targets Ther. 2015, 8, 3159-3167. [PubMed]

137. Yang, F.; Yin, Y.; Wang, F.; Wang, Y.; Zhang, L.; Tang, Y.; Sun, S. miR-17-5p Promotes migration of human hepatocellular carcinoma cells through the p38 mitogen-activated protein kinase-heat shock protein 27 pathway. Hepatology 2010, 51, 1614-1623. [CrossRef] [PubMed]

138. Shigoka, M.; Tsuchida, A.; Matsudo, T.; Nagakawa, Y.; Saito, H.; Suzuki, Y.; Aoki, T.; Murakami, Y.; Toyoda, H.; Kumada, T.; et al. Deregulation of miR-92a expression is implicated in hepatocellular carcinoma development. Pathol. Int. 2010, 60, 351-357. [CrossRef] [PubMed]

139. Wang, L.; Wu, J.; Xie, C. miR-92a promotes hepatocellular carcinoma cells proliferation and invasion by FOXA2 targeting. Iran J. Basic Med. Sci. 2017, 20, 783-790. [PubMed]

140. Zhang, Y.; Zhang, D.; Jiang, J.; Dong, L. Loss of miR-638 promotes invasion and epithelial-mesenchymal transition by targeting $\mathrm{SOX}_{2}$ in hepatocellular carcinoma. Oncol. Rep. 2017, 37, 323-332. [CrossRef] [PubMed]

141. Yan, S.R.; Liu, Z.J.; Yu, S.; Bao, Y.X. Investigation of the value of miR-21 in the diagnosis of early stage HCC and its prognosis: A meta-analysis. Genet. Mol. Res. 2015, 14, 11573-11586. [CrossRef] [PubMed] 
142. Weber, J.A.; Baxter, D.H.; Zhang, S.; Huang, D.Y.; Huang, K.H.; Lee, M.J.; Galas, D.J.; Wang, K. The microRNA spectrum in 12 body fluids. Clin. Chem. 2010, 56, 1733-1741. [CrossRef] [PubMed]

143. Lan, H.; Lu, H.; Wang, X.; Jin, H. MicroRNAs as potential biomarkers in cancer: Opportunities and challenges. Biomed. Res. Int. 2015, 2015, 125094. [CrossRef] [PubMed]

144. Wang, J.; Huang, S.K.; Zhao, M.; Yang, M.; Zhong, J.L.; Gu, Y.Y.; Peng, H.; Che, Y.Q.; Huang, C.Z. Identification of a circulating microRNA signature for colorectal cancer detection. PLoS ONE 2014, 9, e87451. [CrossRef] [PubMed]

145. Toiyama, Y.; Hur, K.; Tanaka, K.; Inoue, Y.; Kusunoki, M.; Boland, C.R.; Goel, A. Serum miR-200c is a novel prognostic and metastasis-predictive biomarker in patients with colorectal cancer. Ann. Surg. 2014, 259, 735-743. [CrossRef] [PubMed]

146. Hibner, G.; Kimsa-Furdzik, M.; Francuz, T. Relevance of MicroRNAs as Potential Diagnostic and Prognostic Markers in Colorectal Cancer. Int. J. Mol. Sci. 2018, 19, 2944. [CrossRef] [PubMed]

(C) 2018 by the authors. Licensee MDPI, Basel, Switzerland. This article is an open access article distributed under the terms and conditions of the Creative Commons Attribution (CC BY) license (http://creativecommons.org/licenses/by/4.0/). 